2015

\title{
VARIABILITY OF NO AND NO2 ABOVE THE SNOWPACK AT SUMMIT, GREENLAND
}

Zhixin Wang

Michigan Technological University

Follow this and additional works at: https://digitalcommons.mtu.edu/etds

Part of the Atmospheric Sciences Commons

Copyright 2015 Zhixin Wang

\section{Recommended Citation}

Wang, Zhixin, "VARIABILITY OF NO AND NO2 ABOVE THE SNOWPACK AT SUMMIT, GREENLAND", Master's Thesis, Michigan Technological University, 2015.

https://doi.org/10.37099/mtu.dc.etds/1006

Follow this and additional works at: https://digitalcommons.mtu.edu/etds

Part of the Atmospheric Sciences Commons 


\title{
VARIABILITY OF NO AND $\mathrm{NO}_{2}$ ABOVE THE SNOWPACK AT SUMMIT, GREENLAND
}

\author{
By \\ Zhixin Wang
}

\begin{abstract}
A THESIS
Submitted in partial fulfillment of the requirements for the degree of MASTER OF SCIENCE

In Geology
\end{abstract}

MICHIGAN TECHNOLOGICAL UNIVERSITY

2015

(C) 2015 Zhixin Wang 
This thesis has been approved in partial fulfillment of the requirements for the Degree of MASTER OF SCIENCE in Geology.

Department of Geological/Mining Engineering and Sciences

\author{
Thesis Advisor: $\quad$ Louisa Kramer \\ Committee Member: $\quad$ Shiliang $W u$ \\ Committee Member: Paul Doskey \\ Department Chair: John Gierke
}




\section{Table of Contents}

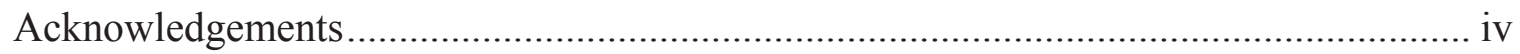

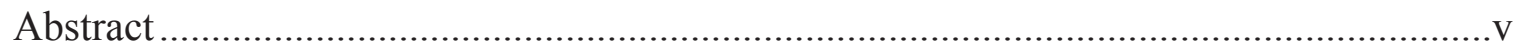

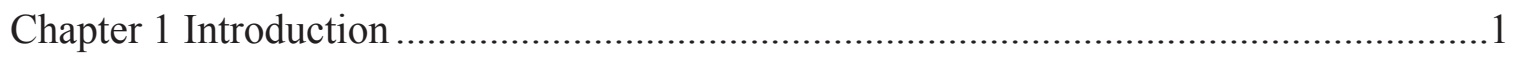

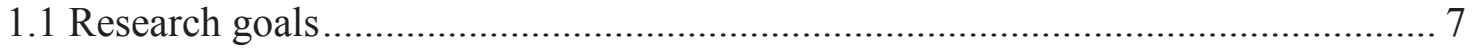

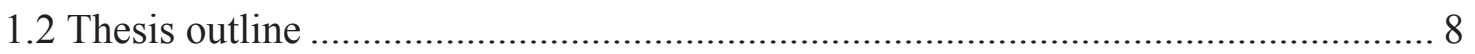

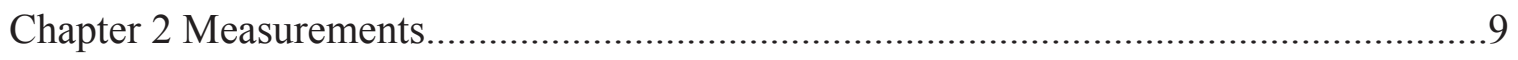

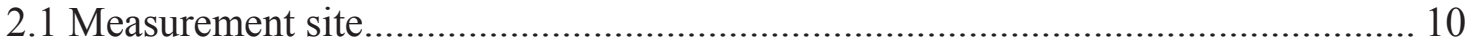

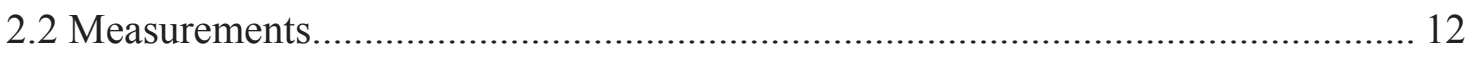

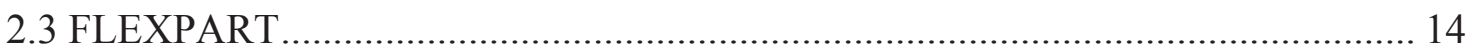

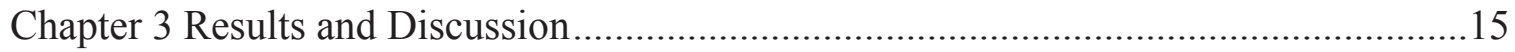

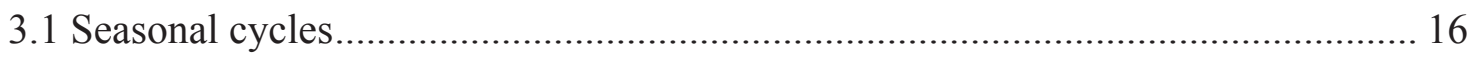

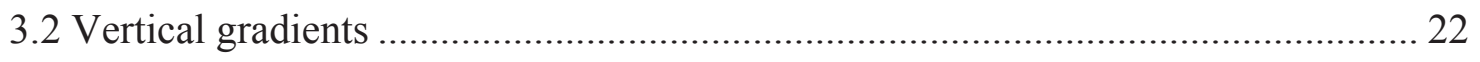

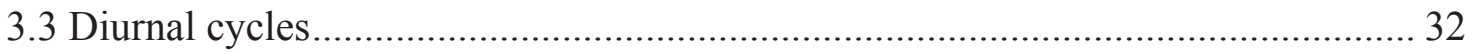

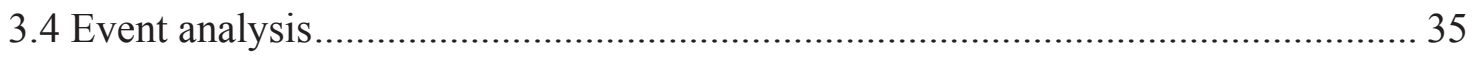

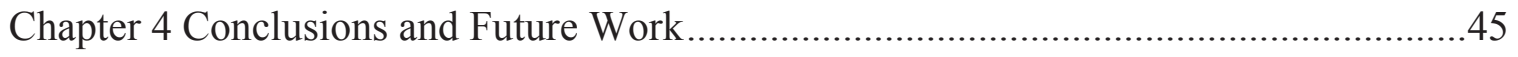

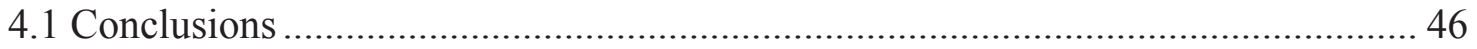

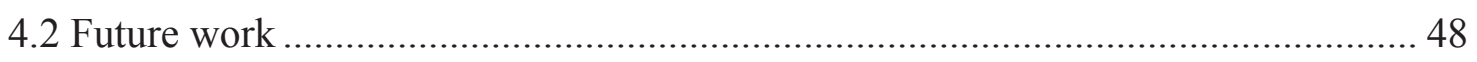

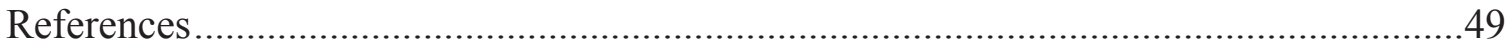




\section{Acknowledgements}

I would like to thank many people who helped me a lot during my study at Michigan Tech.

First of all, I would like to thank my advisor, Dr. Louisa Kramer. She is always patient and trustful. Her enthusiasm for polar research is very impressive. I really appreciate the unique opportunity she offered me to study polar atmospheric science and do field work at Summit, Greenland, which is the greatest experience I have ever had in my life. It is a pity that she will return to England soon. Her departure is totally a loss to our department. I wish she would lead a happy life in her country. Secondly, I would like to thank my committee members, Professor Paul Doskey, Dr. Shiliang Wu, and Dr. Simon Carn, for their instructions in their classes.

Further acknowledgements would go to my best friends for their consistent support and help. I would like to especially thank Yaoxian Huang, Shichang Ma, Bo Zhang, and Huanhuan Zhu, who are always ready to help me in my study and daily life. They made me feel like being at home in Tech. I would like to additionally thank my former and current housemates Bing Han, Libin Jia, Yun Liu, Mu Yuan, Mengmeng Qiao and Lukai Zhai, my next door friend Huanxin Zhang, my officemates Rachel Hetherington and Chuck Holmes, and Lin Liu, Meng Tang, etc., with whom I came to Tech. Thanks for their company.

In addition, thank our department staff Ms. Amie Ledgerwood and Ms. Kelly McLean, who have helped me deal with my funding, reimbursements, and paper work since the day I came to Tech.

Last but not the least, biggest thanks is given to my parents, elder brother and elder sister, for their consistent support, understanding, and help all through my life.

Thank you all! 


\section{Abstract}

Nitric oxide (NO) and nitrogen dioxide $\left(\mathrm{NO}_{2}\right)$ were measured at levels of approximately $7.5 \mathrm{~m}, 3 \mathrm{~m}$, and $0.5 \mathrm{~m}$ above the surface snowpack at Summit, Greenland from July 2008 to July 2010, respectively, with two sets of instrument systems. Instrument I measured NO and $\mathrm{NO}_{2}$ at levels of $3 \mathrm{~m}$ and $0.5 \mathrm{~m}$ with two inlets, and instrument II measured $\mathrm{NO}$ and $\mathrm{NO}_{2}$ at a level of $7.5 \mathrm{~m}$ plus total reactive nitrogen oxides $\left(\mathrm{NO}_{y}\right)$ at the same level with one inlet. Compared to previous measurements, the data provided the first year-round simultaneous record of $\mathrm{NO}$ and $\mathrm{NO}_{2}$ at different levels above the snowpack at a high latitude Arctic site.

Apparent seasonal and diurnal cycles were observed for both $\mathrm{NO}$ and $\mathrm{NO}_{2}$ at different levels. NO reached high levels when solar radiation was high from late spring to summer in a seasonal scale and at around noon in a diurnal scale, while $\mathrm{NO}_{2}$ reached high levels from early spring to early fall in a seasonal scale and from afternoon to night in a diurnal scale. The vertical gradients of $\mathrm{NO}$ and $\mathrm{NO}_{2}$ between $3 \mathrm{~m}$ and $0.5 \mathrm{~m}$ above the snowpack suggested the emission of NO from the surface snowpack. An improved mechanism for snowpack photochemistry at Summit is proposed to explain the seasonal variability of NO and $\mathrm{NO}_{2}$. Furthermore, a pollution event study showed that FLEXPART retroplume simulations were in agreement with the measurements. During polar night season, $\mathrm{NO}_{2}$ exactly followed FLEXPART simulation. Nitrate accumulation through snowpack deposition was proposed to attribute $\mathrm{NO}_{2}$ increase in early spring. In sunlight season, nitrate deposition was proposed to occur during the pollution events and was re-emitted from the snowpack via photolysis after the event, resulting in subsequent $\mathrm{NO}_{2}$ increase. 


\section{Chapter 1 Introduction}


The nitrogen oxides $\left(\mathrm{NO}_{\mathrm{x}}\right)$, which includes nitric oxide $(\mathrm{NO})$ and nitrogen dioxides $\left(\mathrm{NO}_{2}\right)$, are very important atmospheric components due in part to the role they play in atmospheric chemistry. The catalytic formation of tropospheric ozone is highly dependent on the levels of $\mathrm{NO}_{\mathrm{x}}$ during the oxidation of carbon monoxide $(\mathrm{CO})$, methane $\left(\mathrm{CH}_{4}\right)$, and other hydrocarbons (Crutzen 1973, 1979; Zimmerman et al., 1978). The following reactions involving $\mathrm{CO}$ take place to produce ozone:

$$
\begin{aligned}
& \mathrm{CO}+\mathrm{OH} \rightarrow \mathrm{H}+\mathrm{CO}_{2} \\
& \mathrm{H}+\mathrm{O}_{2}+\mathrm{M} \rightarrow \mathrm{HO}_{2}+\mathrm{M} \\
& \mathrm{HO}_{2}+\mathrm{NO} \rightarrow \mathrm{OH}+\mathrm{NO}_{2} \\
& \mathrm{NO}_{2}+h v \rightarrow \mathrm{NO}+\mathrm{O} \quad \lambda \leq \sim 400 \mathrm{~nm} \\
& \mathrm{O}+\mathrm{O}_{2}+\mathrm{M} \rightarrow \mathrm{O}_{3}+\mathrm{M}
\end{aligned}
$$

$$
\text { Net: } \mathrm{CO}+2 \mathrm{O}_{2} \rightarrow \mathrm{CO}_{2}+\mathrm{O}_{3}
$$

where $\mathrm{M}$ denotes any molecule in the atmosphere that absorbs the excess energy of the reactants. $\mathrm{NO}_{\mathrm{x}}$ serves as a catalyst in this mechanism. The net reaction 1.6 indicates that one ozone molecule is produced per oxidation of one $\mathrm{CO}$ molecule. In case of methane and other hydrocarbons, ozone is produced through a set of reactions below:

$$
\begin{aligned}
& \mathrm{R}+\mathrm{O}_{2}+\mathrm{M} \rightarrow \mathrm{RO}_{2}+\mathrm{M} \\
& \mathrm{RO}_{2}+\mathrm{NO} \rightarrow \mathrm{RO}+\mathrm{NO}_{2} \\
& \mathrm{NO}_{2}+h v \rightarrow \mathrm{NO}+\mathrm{O} \quad \lambda \leq \sim 400 \mathrm{~nm} \\
& \mathrm{O}+\mathrm{O}_{2}+\mathrm{M} \rightarrow \mathrm{O}_{3}+\mathrm{M}
\end{aligned}
$$

Net: $\mathrm{R}+2 \mathrm{O}_{2} \rightarrow \mathrm{RO}+\mathrm{O}_{3}$ 
where the symbol $\mathrm{R}$ represents radical species like $\mathrm{CH}_{3}$, and $\mathrm{CH}_{3} \mathrm{C}(\mathrm{O})$, which are intermediate products of hydrocarbon oxidation in the atmosphere (Altshuller, Bufalini, 1971; Demerjian et al., 1974). $\mathrm{R}$ also can be $\mathrm{H}$ from reaction 1.1 as the intermediate product of $\mathrm{CO}$ oxidation. Through this scheme an oxygen molecule is dissociated into $\mathrm{O}$, which cannot take place in the troposphere due to insufficient solar energy (Crutzen, 1979).

However, if there is insufficient $\mathrm{NO}$, the following reactions may take place, to take $\mathrm{CO}$ for example:

$$
\begin{gathered}
\mathrm{CO}+\mathrm{OH} \rightarrow \mathrm{H}+\mathrm{CO}_{2} \\
\mathrm{H}+\mathrm{O}_{2}+\mathrm{M} \rightarrow \mathrm{HO}_{2}+\mathrm{M} \\
\mathrm{HO}_{2}+\mathrm{HO}_{2} \rightarrow \mathrm{H}_{2} \mathrm{O}_{2}+\mathrm{O}_{2} \\
\mathrm{H}_{2} \mathrm{O}_{2}+h v \rightarrow 2 \mathrm{OH}
\end{gathered}
$$

Net: $2 \mathrm{CO}+\mathrm{O}_{2} \rightarrow 2 \mathrm{CO}_{2}$

or:

$$
\begin{gathered}
\mathrm{CO}+\mathrm{OH} \rightarrow \mathrm{H}+\mathrm{CO}_{2} \\
\mathrm{H}+\mathrm{O}_{2}+\mathrm{M} \rightarrow \mathrm{HO}_{2}+\mathrm{M} \\
\mathrm{HO}_{2}+\mathrm{O}_{3} \rightarrow \mathrm{OH}+2 \mathrm{O}_{2}
\end{gathered}
$$

$$
\text { Net: } \mathrm{CO}+\mathrm{O}_{3} \rightarrow \mathrm{CO}_{2}+\mathrm{O}_{2}
$$

The relative rates of reaction 1.3 and reaction 1.14, therefore, will determine whether ozone is produced or lost in the troposphere. A critical volume mixing ratio of NO can be estimated by comparing the rate constants of reaction 1.3 and reaction 1.14, above which ozone production is larger than its destruction. In a typical clean air the critical mixing ratio 
of NO is about 5 pptv (Howard et al., 1977). However, if an increase occurs to NO even under a low level, ozone destruction will be reduced and therefore ozone will increase (Honrath, 1991).

Besides controlling ozone production in the troposphere, through the following reactions, $\mathrm{NO}_{\mathrm{x}}$ has much effect on the concentration of tropospheric hydroxyl radical $(\mathrm{OH})$, which can remove a variety of atmospheric compounds like $\mathrm{CO}, \mathrm{CH}_{4}$, and halocarbons (Levy, 1971; Logan 1983):

$$
\begin{aligned}
& \mathrm{O}_{3}+h v \rightarrow \mathrm{O}\left({ }^{1} \mathrm{D}\right)+\mathrm{O}_{2} \quad \lambda \leq \sim 310 \mathrm{~nm} \\
& \mathrm{O}\left({ }^{1} \mathrm{D}\right)+\mathrm{H}_{2} \mathrm{O} \rightarrow 2 \mathrm{OH} .
\end{aligned}
$$

$\mathrm{O}\left({ }^{1} \mathrm{D}\right)$ is mainly deactivated by $\mathrm{N}_{2}$ and $\mathrm{O}_{2}$ molecules to ground state $\mathrm{O}\left({ }^{3} \mathrm{P}\right)$, Nitric acid $\left(\mathrm{HNO}_{3}\right)$, product of reaction of $\mathrm{OH}$ with $\mathrm{NO}_{2}$, is a major component of acid precipitation (Galloway, Likens, 1981; Logan, 1983):

$$
\mathrm{NO}_{2}+\mathrm{OH}+\mathrm{M} \rightarrow \mathrm{HNO}_{3}+\mathrm{M}
$$

The life time of $\mathrm{NO}_{\mathrm{x}}$ is rather short. This reaction, followed by rainout or surface deposition of $\mathrm{HNO}_{3}$, helps to prolong the lifetimes of $\mathrm{NO}_{\mathrm{x}}$ to $\sim 1-2$ days at mid-latitudes in summer and $\sim 10$ days in winter (Logan et al., 1981).

$\mathrm{NO}$ can be rapidly oxidized to $\mathrm{NO}_{2}$ by ozone in the atmosphere. $\mathrm{NO}_{2}$ can be converted to NO by solar radiation. The relevant reactions are as follows:

$$
\begin{aligned}
& \mathrm{NO}+\mathrm{O}_{3} \rightarrow \mathrm{NO}_{2}+\mathrm{O}_{2} \\
& \mathrm{NO}_{2}+h v \rightarrow \mathrm{NO}+\mathrm{O} \quad \lambda \leq \sim 400 \mathrm{~nm} \\
& \mathrm{O}+\mathrm{O}_{2}+\mathrm{M} \rightarrow \mathrm{O}_{3}+\mathrm{M} .
\end{aligned}
$$

This interconversion between $\mathrm{NO}$ and $\mathrm{NO}_{2}$ is very fast at midday of mid-latitude with a time constant of minutes. Therefore, $\mathrm{NO}$ and $\mathrm{NO}_{2}$ are often treated as a single entity, $\mathrm{NO}_{\mathrm{x}}$. 
At global scale, the dominant sources of tropospheric nitrogen oxides primarily include fossil fuel combustion, biomass burning, biogenic emissions from soil, and lightning (Logan 1983). Combustions of fossil fuel and biomass burning account for approximate $50 \%$ and $20 \%$ of the total $\mathrm{NO}_{\mathrm{x}}$ emission, respectively (Delmas, et al., 1997), which result from production of $\mathrm{NO}$ from $\mathrm{N}_{2}$ and $\mathrm{O}_{2}$ combustion under high-temperature (Seinfeld, 1975). Anthropogenic emissions have substantially increased in recent decades due to fossil fuel combustion from observations.

Anthropogenic emissions are distributed in industrialized continental areas, and the impact they have on $\mathrm{NO}_{\mathrm{x}}$ concentrations in remote regions is limited due to the rather short lifetime of $\mathrm{NO}_{\mathrm{x}}$. However, $\mathrm{NO}_{\mathrm{x}}$ still can be transported over a long range to remote regions like the Artic in the form of relatively stable reservoir species such as peroxyacetyl nitrate (PAN) (Singh and Hanst, 1981; Singh et al., 1986), which is highly stable under low temperature in the free troposphere. PAN is primarily formed from photochemical reactions of a variety of hydrocarbons in the presence of $\mathrm{NO}_{\mathrm{x}}$ (Stephens, 1969). The lifetime of PAN is highly temperature-dependent, ranging from days in the mid-latitude to three months in the midtroposphere (Singh, 1987). Therefore, it is proposed that nitrogen oxides are transported into the free troposphere in the form of PAN. It is a mechanism for the transport of $\mathrm{NO}_{\mathrm{x}}$ from polluted areas to the free troposphere that PAN will be thermally decomposed and release $\mathrm{NO}_{\mathrm{x}}$ with rising temperatures in the lower troposphere (Singh and Hanst, 1981).

In the Arctic, in-situ measurements of $\mathrm{NO}_{\mathrm{x}}, \mathrm{NO}_{\mathrm{y}}, \mathrm{PAN}$, and other atmospheric species are very scarce, especially year-round and long-term observations. Here $\mathrm{NO}_{\mathrm{y}}$ refers to the total reactive oxidized nitrogen, including $\mathrm{NO}_{x}, \mathrm{HNO}_{3}, \mathrm{PAN}$, and other reactive nitrogen species in the troposphere. Thus, $\mathrm{NO}_{\mathrm{y}}=\mathrm{NO}+\mathrm{NO}_{2}+\mathrm{HNO}_{3}+\mathrm{PAN}+\mathrm{NO}_{3}+\mathrm{N}_{2} \mathrm{O}_{5}+$ others. There is evidence that PAN accounts for a primary fraction of $\mathrm{NO}_{\mathrm{y}}$ in the Arctic free troposphere (Sandholm et al., 1992; Singh et al., 1992; Kramer et al., 2014).

$\mathrm{NO}, \mathrm{NO}_{x}$, and $\mathrm{NO}_{\mathrm{y}}$ were measured in the Arctic region in March 1983 on several aircraft flights (Dickerson, 1985). The measurements presented that NO mixing ratio was always below the detection limit of $10 \mathrm{ppt}, \mathrm{NO}_{\mathrm{x}}$ mixing ratio was $\sim 600 \mathrm{ppt}$ in the boundary layer, 
$\mathrm{NO}_{\mathrm{y}}$ mixing ratio was $1500 \mathrm{ppt}$, and ratios of $\mathrm{NO}_{\mathrm{x}}$ and $\mathrm{NO}_{\mathrm{y}}$ were 0.81 near the surface and 0.46 at $6400 \mathrm{~m}$, probably due to presence of higher levels of PAN or other organic nitrate compounds in the free troposphere (Dickerson, 1985). PAN mixing ratio was measured individually during springtime of 1986, and 1989 at Albert, Canada, indicating that PAN is an important component of $\mathrm{NO}_{\mathrm{y}}$ in the springtime Arctic (Bottenheim et al., 1986; Barrie et al., 1989; Bottenheim et al., 1989). Ground-level mixing ratios of $\mathrm{NO}_{\mathrm{y}}$ and NO were measured at Barrow, Alaska in summer 1988, spring 1989, and March-December 1990, which revealed a seasonal cycle of $\mathrm{NO}_{\mathrm{y}}$ with high values in early spring (median 560-620 ppt) and $\sim 70$ ppt (median) during summer, an hourly average of NO $<8$ ppt and a pulse to 35 ppt (maximum hourly average) in late spring, and a positive correlation between mixing ratios of $\mathrm{NO}_{\mathrm{y}}$ and $\mathrm{O}_{3}$ (Honrath, 1991).

Snowpack $\mathrm{NO}_{\mathrm{x}}$ photochemistry has been a hot topic in recent years. Field measurements and lab experiments were conducted from polar regions (Honrath et al., 1999; Beine et al., 2002; Jones et al., 2000) to mid-latitudes (Honrath et al., 2000b). The snowpack is not only a receptor but also a source for many trace gases. There is evidence that $\mathrm{NO}_{\mathrm{x}}$ is produced in, and released from, the snowpack through nitrate photodecomposition at Summit, Greenland in summertime when insolation is available, resulting in elevated $\mathrm{NO}_{\mathrm{x}}$ levels in the boundary layer (Honrath et al., 1999; Dibb et al., 2002). Measurements of vertical gradients of $\mathrm{NO}_{x}, \mathrm{HONO}$, and $\mathrm{HNO}_{3}$ at Summit in summer 2000 in the lower 1-2 $\mathrm{m}$ above the snowpack indicated that $\mathrm{NO}_{x}$ and $\mathrm{HONO}$ emissions from the snowpack and $\mathrm{HNO}_{3}$ deposition into the snowpack occurred simultaneously, and the average emissions is much larger than the average deposition, implying $\mathrm{NO}_{\mathrm{x}}$ export occurrence from the boundary layer (Honrath et al., 2002). Isotope measurements of nitrogen and oxygen of $\mathrm{NO}_{3}^{-}$in snowpack at Summit indicate that loss of $\mathrm{NO}_{3}^{-}$from snow due to photolysis and/or evaporation during the day is primarily recovered at night through $\mathrm{NO}_{\mathrm{x}}$ deposition to $\mathrm{HNO}_{3}$ (Steig and Sigman, 2004). A year long investigation of $\mathrm{NO}_{3}^{-}$suggests that a maximum of $7 \%$ of $\mathrm{NO}_{3}^{-}$is lost from snowpack annually (Burkhart et al., 2004). The proposed mechanism for the production of $\mathrm{NO}, \mathrm{NO}_{2}$, and $\mathrm{HONO}$ in snowpack is nitrate photolysis via the reactions below: 


$$
\begin{aligned}
& \mathrm{NO}_{3}^{-}+h v \rightarrow \mathrm{NO}_{2}+\mathrm{O}^{-} \\
& \left.\mathrm{NO}_{3}^{-}+h v \rightarrow \mathrm{NO}_{2}^{-}+\mathrm{O}^{3} \mathrm{P}\right) \\
& \mathrm{NO}_{2}^{-}+h v \rightarrow \mathrm{NO}+\mathrm{O}^{-} \\
& \mathrm{NO}_{2}^{-}+\mathrm{OH} \rightarrow \mathrm{NO}_{2}+\mathrm{OH}^{-},
\end{aligned}
$$

where reaction 1.20 is more efficient than reaction 1.21 by roughly a factor of 8 to 9 from two lab experiments in aqueous phase (Warneck and Wurzinger, 1988) and on ice surfaces (Dubowski et al., 2001; Grannas et al., 2007).

\subsection{Research goals}

Previous measurements in the Arctic usually focused on $\mathrm{NO}_{\mathrm{x}}$ and were very short or not consecutive for a whole year, which are inadequate for fully and precisely understanding the magnitude and diurnal and seasonal variability of $\mathrm{NO}$ and $\mathrm{NO}_{2}$. Honrath (1991) performed measurements of $\mathrm{NO}_{\mathrm{y}}$ and $\mathrm{NO}$ in summer 1988, spring 1989, and MarchDecember 1990 with month gaps in one single year. The $\mathrm{NO}, \mathrm{NO}_{2}$, and $\mathrm{NO}_{\mathrm{y}}$ data this thesis used were collected with two separate instrument systems, from July 2008 to July 2010, one measuring $\mathrm{NO}, \mathrm{NO}_{2}$, and $\mathrm{NO}_{y}$ at a level of approximately $7.5 \mathrm{~m}$ above the snowpack, the other measuring $\mathrm{NO}$ and $\mathrm{NO}_{2}$ at levels of $3.0 \mathrm{~m}$, and $0.5 \mathrm{~m}$. The measurements provided the first year-round concurrent record of $\mathrm{NO}_{\mathrm{x}}$ at 3 levels at a high latitude Arctic site. Measurements at three levels above the snowpack provided a way to investigate snowpack emission and its impact on seasonal and diurnal cycles of $\mathrm{NO}$ and $\mathrm{NO}_{2}$. They also made it possible to investigate the impact of boundary layer conditions on the diurnal cycles. Boundary layer variability was proposed to have a significant impact on the diurnal cycles of $\mathrm{NO}_{\mathrm{x}}$ at Dome $\mathrm{C}$, Antarctica, which reached maximum height in the early afternoon and lower height in the evening, leading to dilution of $\mathrm{NO}_{\mathrm{x}}$ concentration combined with convective upward mixing of snowpack $\mathrm{NO}_{\mathrm{x}}$ emission and accumulation of snowpack $\mathrm{NO}_{\mathrm{x}}$ emission, respectively (Frey et al., 2013). Boundary layer conditions may also be a factor impacting levels of trace gases at Summit through diurnal variation (Cohen, et al., 2007; Van Dam et al., 2013). 
Here, the first year-round measurements of $\mathrm{NO}$ and $\mathrm{NO}_{2}$ mixing ratios at three levels above the snowpack at Summit could help us better understand the seasonal and diurnal cycles of $\mathrm{NO}$ and $\mathrm{NO}_{2}$ at different levels, snowpack emission mechanism, vertical gradients and the interaction of snowpack emission with seasonal and diurnal variability and vertical gradients. Furthermore, combined with FLEXPART retroplume analyses, we can better understand the impact of long range transport emissions on the measurement site and how nitrate deposition and re-emission occur during and after a pollution event.

Using these measurements the following goals were addressed in this thesis:

1. To identify and describe the seasonal cycles of $\mathrm{NO}$ and $\mathrm{NO}_{2}$ from the surface up to approximately $7.5 \mathrm{~m}$ above the snowpack in the Arctic boundary layer at Summit, Greenland.

2. To verify whether $\mathrm{NO}_{\mathbf{x}}$ is released from the snowpack with $\mathrm{NO}$ and $\mathrm{NO}_{2}$ gradients and propose a mechanism for snowpack photochemistry at Summit.

3. To determine how the diurnal cycles of $\mathrm{NO}$ and $\mathrm{NO}_{2}$ change from the surface up to the top of the snow tower.

4. To observe changes of $\mathrm{NO}_{\mathrm{x}}$ above the snowpack just after a large pollution event and compare $\mathrm{NO}$ and $\mathrm{NO}_{2}$ before, during and after each event.

\subsection{Thesis outline}

The thesis includes 5 chapters. In chapter 1, chemistry, sources, long range transport, previous measurements and snowpack photochemistry of nitrogen oxides, plus research goals and thesis outline are covered. Chapter 2 discusses the introduction of measurement site, instrumentation, measurement method, and FLEXPART model. In chapter 3, seasonal cycles, vertical gradients, diurnal cycles of $\mathrm{NO}$ and $\mathrm{NO}_{2}$, plus pollution transport events are analyzed with the data measured at Summit. Chapter 4 covers conclusions and future work. This final section is a summary on what the final results have shown and what can be derived. 


\section{Chapter 2 Measurements}




\subsection{Measurement site}

The measurements of $\mathrm{NO}, \mathrm{NO}_{2}$, and $\mathrm{NO}_{\mathrm{y}}$ were conducted from July 2008 to July 2010 at the GEOSummit Station (hereafter called Summit), Greenland ( $72.34^{\circ} \mathrm{N}, 38.29^{\circ} \mathrm{W}, 3212$ m.a.s.l). Summit is located on the apex of the Greenland Ice Sheet. It is approximately 360 $\mathrm{km}$ from the east coast and $500 \mathrm{~km}$ from the west coast of Greenland (Figure 2.1). It is relatively free from local pollution. Furthermore, due to its high altitude and proximity to North America and Europe, Summit is an ideal location for sampling long-transported anthropogenic emissions and biomass burning emissions from North America, Europe and forest fires in the troposphere.

One inlet for Instrument I at a level of approximately $7.5 \mathrm{~m}$ and two inlets for Instrument II at levels of approximately $3 \mathrm{~m}$ and $0.5 \mathrm{~m}$, above the snow surface were installed on the tower (Figure 2.2). Instrument I measures $\mathrm{NO}_{\mathrm{x}}$ and $\mathrm{NO}_{\mathrm{y}}$, which was developed for the project "A study of biomass-burning and anthropogenic impacts on arctic tropospheric chemistry using measurements at Summit, Greenland as part of the POLARCAT IPY project (NASA grant NNX07AR26G)". Instrument II measures $\mathrm{NO}_{\mathrm{x}}$ only, which was built for the project "Collaborative research: A synthesis of existing and new observations of air-snowpack exchanges to assess the Arctic tropospheric ozone budget (NSF Award number 0713943$)$ )". The tower is approximately $660 \mathrm{~m}$ south-west of the main camp within the "clean air" sector, where the impact from station emission can be minimized so long as there is no north wind blowing from the main camp. Tubing and cables were routed through a heated pipe to a buried laboratory facility. 


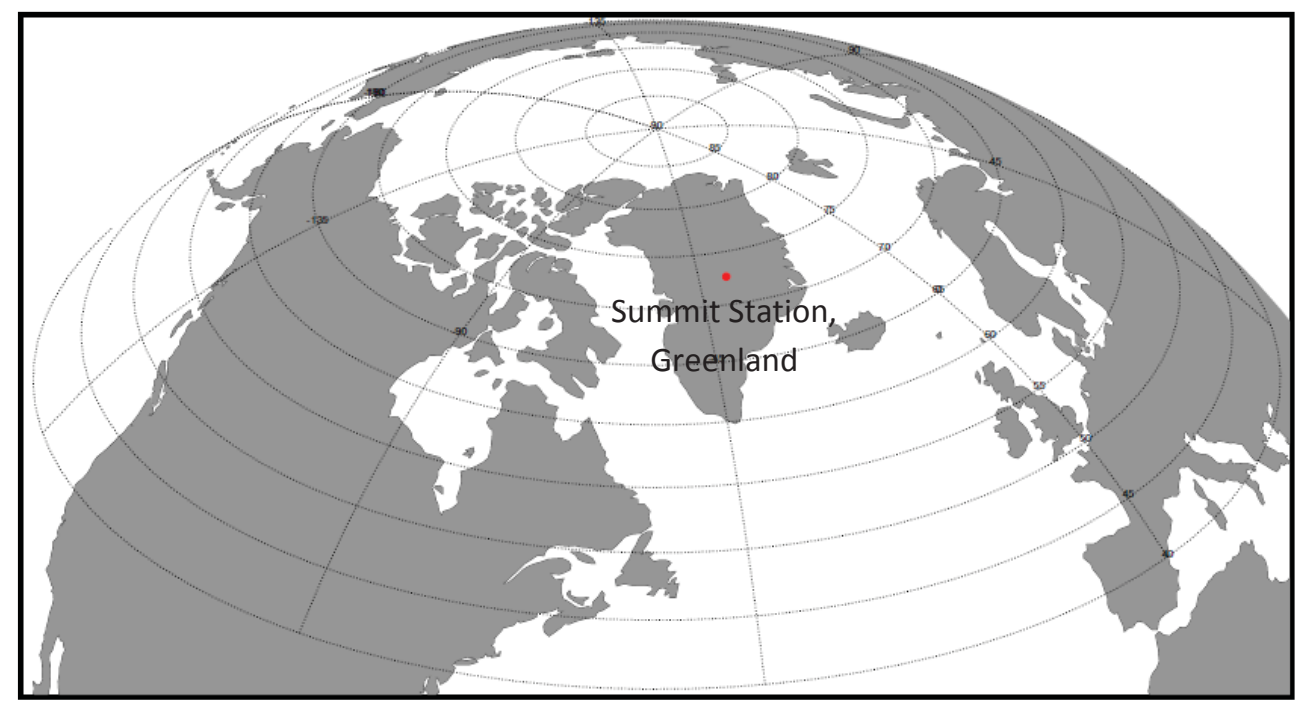

Figure 2.1. Location of the GEOSummit Station in Greenland

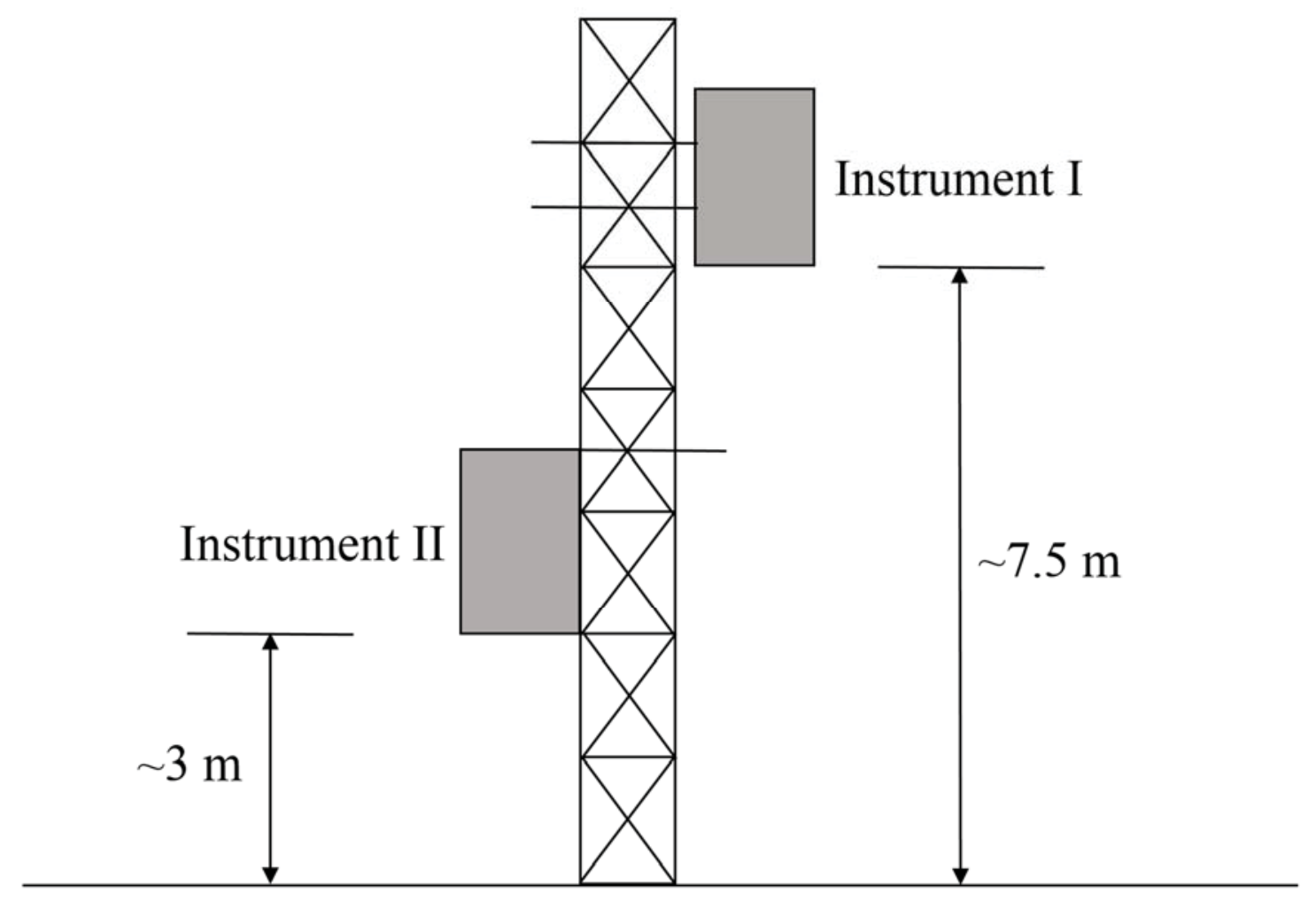

Figure 2.2. Instrument I and Instrument II on the snow tower. 


\subsection{Measurements}

NO is measured with an automated ozone-induced chemiluminescence detection system (Ridley and Grahek, 1990). Chemiluminescence can be defined as emission of nonionizing radiation like ultraviolet, visible, or infra-red light from a molecule or an atom as a result of the transition of an electronically excited state in a chemical reaction without an apparent change in temperature (Navas et al., 1997). Ozone-induced chemiluminescence technique is of great importance in analytical chemistry and is widely used in determination of NO and a great variety of atmospheric compounds. The following reactions will occur during the process:

$$
\begin{aligned}
& \mathrm{O}_{3}+\mathrm{NO} \rightarrow \mathrm{NO}_{2}{ }^{*}+\mathrm{O}_{2} \\
& \mathrm{NO}_{2}{ }^{*} \rightarrow \mathrm{NO}_{2}+h v \\
& \mathrm{NO}_{2}{ }^{*}+\mathrm{M} \rightarrow \mathrm{NO}_{2}+\mathrm{M}
\end{aligned}
$$

$\mathrm{NO}_{2}$ and $\mathrm{NO}_{\mathrm{y}}$ are measured with the same method. Prior to the above process, however, $\mathrm{NO}_{2}$ is photolyzed to $\mathrm{NO}$ with $\mathrm{NO}_{2}$ converter (Kley and Mcfarland, 1980) and $\mathrm{NO}_{\mathrm{y}}$ is converted to $\mathrm{NO}$ with gold-catalyzed $\mathrm{NO}_{\mathrm{y}}$ converter in the presence of $\mathrm{CO}$ (Bollinger et al., 1983; Fahey et al., 1985), respectively.

Instrument I was developed at Michigan Technological University and was based on previous version installed at Summit during campaigns in 1998, 1999, and 2000 (Honrath et al., 1999, 2002; Dibb et al., 2006). Instrument II is a modified version with the $\mathrm{NO}_{\mathrm{y}}$ measuring function removed. Figure 2.3 shows schematic diagram of Instrument I. For Instrument II, no $\mathrm{NO}_{\mathrm{y}}$ converter is installed. 


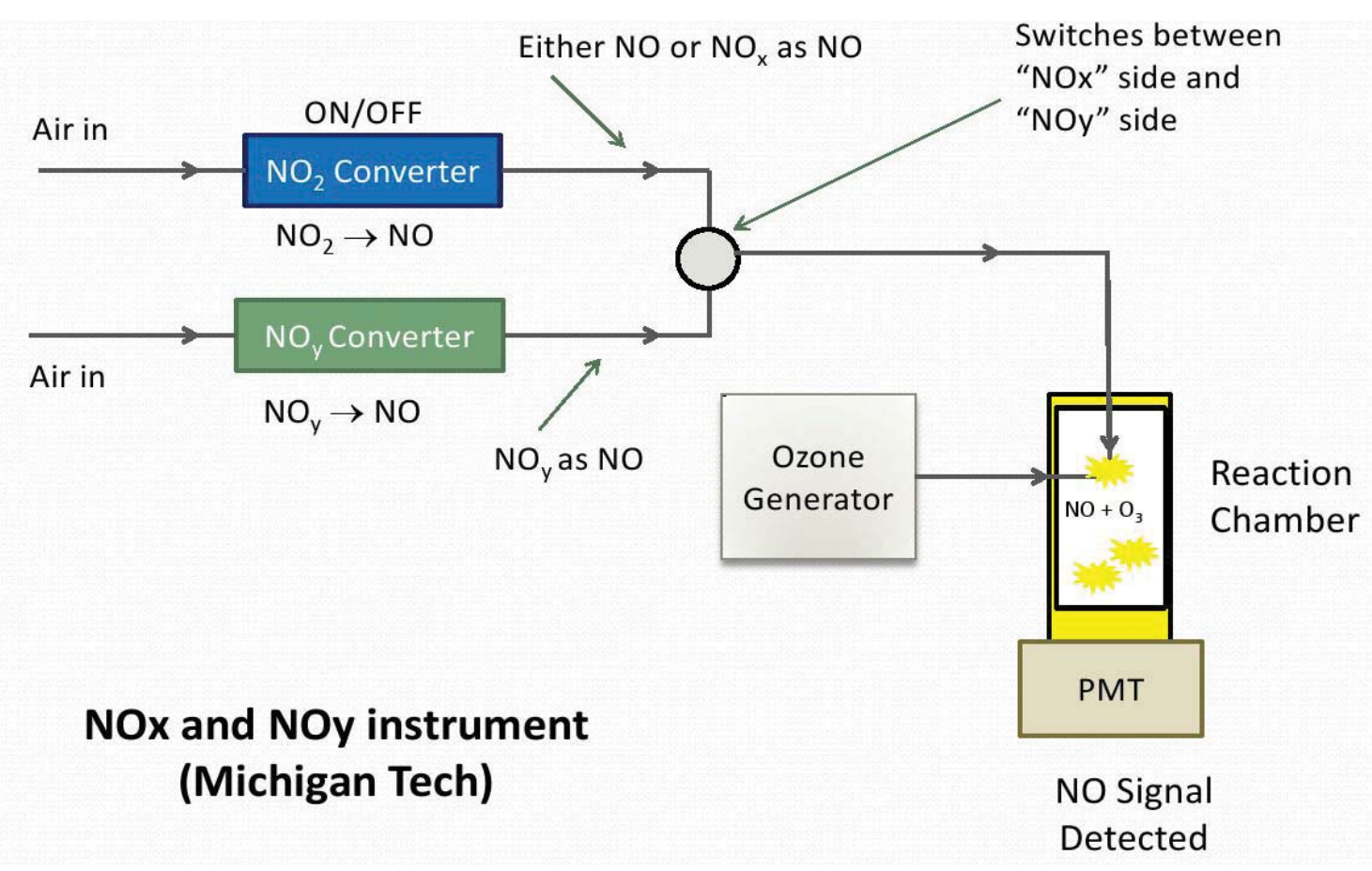

Figure 2.3. Schematic diagram of Instrument I

There are two main types of converters for $\mathrm{NO}_{2}$, thermal converters and photolytic converters. In this instrument system, a photolytic blue LED $\mathrm{NO}_{2}$ converter (Air-Quality Design Inc., Colorado) is utilized. A thermal converter with molybdenum catalyst has a higher efficiency and a longer lifetime, however, it is not specific to $\mathrm{NO}_{2}$ and can also respond to other nitrogen containing species such as nitrous acid (HONO) and PAN, consequently increasing the interferences (Villena et al., 2012). A photolytic converter has a lower conversion efficiency and needs to be calibrated regularly, but it is specific to $\mathrm{NO}_{2}$ and can reduce interferences from other nitrogen species. (Villena et al., 2012). In order to minimize the residence time of $\mathrm{NO}_{2}$ and $\mathrm{NO}_{\mathrm{y}}$ species inside the PFA tubing in Instrument I, the sample mass flow controller (MFC) and the $\mathrm{NO}_{2}$ and $\mathrm{NO}_{y}$ converters are housed inside the inlet box on the tower.

The measurement cycles for both instruments are $10 \mathrm{~min}$, which is very important when we want to measure variability on a short time scale. For instrument I, 30s averages of NO and $\mathrm{NO}_{2}$ and 20s averages of $\mathrm{NO}_{\mathrm{y}}$ were recorded. Zero measurements are performed to determine the interference signal in the reaction chamber. Regular calibrations are needed 
to determine the sensitivity of the instrument and conversion efficiency of $\mathrm{NO}_{2}$ and $\mathrm{NO}_{\mathrm{y}}$ converters. More details about screening and correction of the datasets can refer to Kramer et al. (2014). In this thesis, 30 min averaged $\mathrm{NO}_{\mathrm{x}}$, and $\mathrm{NO}_{\mathrm{y}}$ data were employed. Similar procedures in $\mathrm{NO}_{\mathrm{x}}$ measurements and data processing were performed for Instrument II (Toro, 2011).

\subsection{FLEXPART}

Potential pollution "events" (periods when the site was apparently impacted by local or transported polluted air masses) were identified with FLEXPART (version 8.2) (Kramer et al., 2014). The Lagrangian particle dispersion model FLEXPART simulates long-range atmospheric transport from the sources with European Centre for Medium Range Weather Forecasts (ECMWF) data (forward mode), which can also simulate given receptors back to potential sources (backward mode) (Stohl et al., 2005). In this thesis, FLEXPART backward mode was utilized with black carbon as the tracer for both anthropogenic ( $\mathrm{BC}_{\text {anthro }}$ ) and biomass burning emissions ( $\mathrm{BC}_{\text {fire }}$ ) (Kramer et al., 2014). The data source for $\mathrm{BC}$ anthropogenic and $\mathrm{BC}$ biomass burning emissions tracer, and comparison between $\mathrm{BC}$ tracer and carbon monoxide tracer for anthropogenic emissions are explained in Kramer et al., (2014). 
Chapter 3 Results and Discussion 


\subsection{Seasonal cycles}

Here seasonal cycles of $\mathrm{NO}$ and $\mathrm{NO}_{2}$ were measured and analyzed separately. The time series of daily averaged mixing ratios of $\mathrm{NO}$ and $\mathrm{NO}_{2}$ at three different levels $(7.5 \mathrm{~m}, 3 \mathrm{~m}$, and $0.5 \mathrm{~m}$ ) above the snowpack at Summit, Greenland from July 2008 to July 2010 are displayed in Figure 3.1 and Figure 3.2, respectively. Due to instrument malfunctions there are some gaps within the datasets. For the dataset measured at $7.5 \mathrm{~m}$ above the snowpack with Instrument I (red line), the largest gap is from November 24, 2008 to March 30, 2009. For datasets measured at $3 \mathrm{~m}$ (green line) and $0.5 \mathrm{~m}$ (blue line) above the snowpack with Instrument II, the data in July 2008, September 2008, October 2008, and July 2010 are missing.

For daily mixing ratios of $\mathrm{NO}$, apparent seasonal cycles can be observed in Figure 3.1 with higher levels from late spring to summer and lower levels from fall to early spring. Furthermore, the values at three levels are close to one another and have same trends. The short periods of enhancements with large values are primarily due to anthropogenic and biomass burning emissions transported from North America and Europe (Kramer et al., 2014). Note that Instrument II data records started in August 2008 and due to missing ozone data for data correction no data were measured in the following September and October. As Instrument II has two inlets, ozone data is required to correct the $\mathrm{NO}_{2}$ and $\mathrm{O}_{3}$ reaction in the sampling lines that result in an overestimation of $\mathrm{NO}$ and an underestimation of $\mathrm{NO}_{2}$. So the data in August might not be very reliable. For Instrument I, it has only one inlet and we calibrate at the inlet we use. So the correction is not needed. 


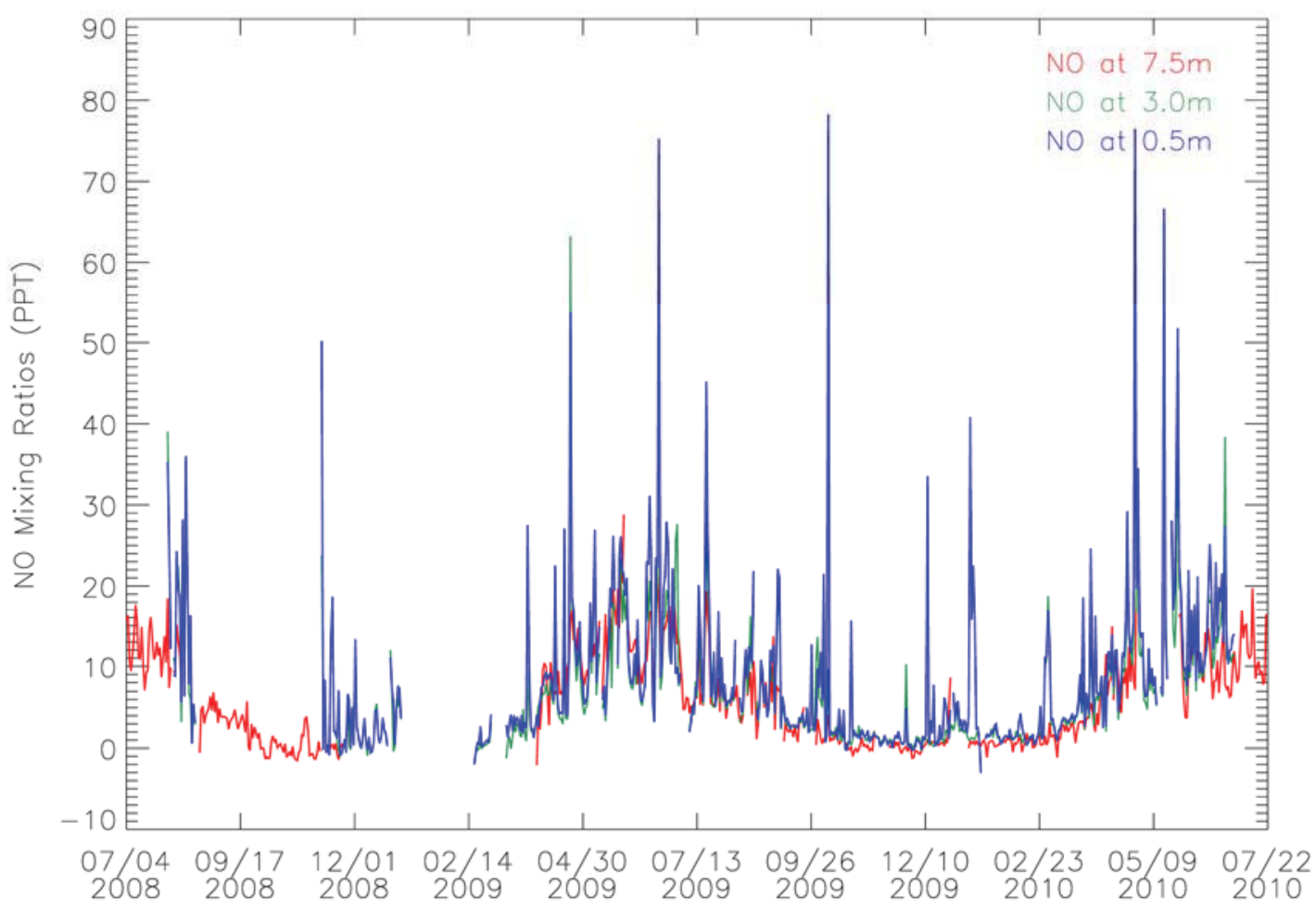

Figure 3.1. Time series of daily averaged mixing ratios of $\mathrm{NO}$ at $7.5 \mathrm{~m}, 3 \mathrm{~m}$, and $0.5 \mathrm{~m}$, respectively, above the snowpack at Summit, Greenland from July 2008 to July 2010.

For $\mathrm{NO}_{2}$ as shown in Figure 3.2, similar seasonal cycles can be observed with higher levels from spring to early fall and lower levels from fall to late winter. The $\mathrm{NO}_{2}$ mixing ratio at $7.5 \mathrm{~m}$ above the snowpack is much lower than those at $3 \mathrm{~m}$ and $0.5 \mathrm{~m}$, especially in spring, while $\mathrm{NO}$ at $7.5 \mathrm{~m}$ is very close to $\mathrm{NO}$ at $0.5 \mathrm{~m}$ and $3 \mathrm{~m}$. The hypothetic mechanism will be discussed in section 3.2. Both $\mathrm{NO}$ and $\mathrm{NO}_{2}$ have many short term enhancements in the time series plots, indicating that external polluted air mass sources transported from lower latitudes, or downward transport from the lower stratosphere, play an important role at this measurement site (Kramer et al., 2014). These events will be identified with FLEXPART retroplume simulations as pollution events and be analyzed for further investigation in Section 3.4. 


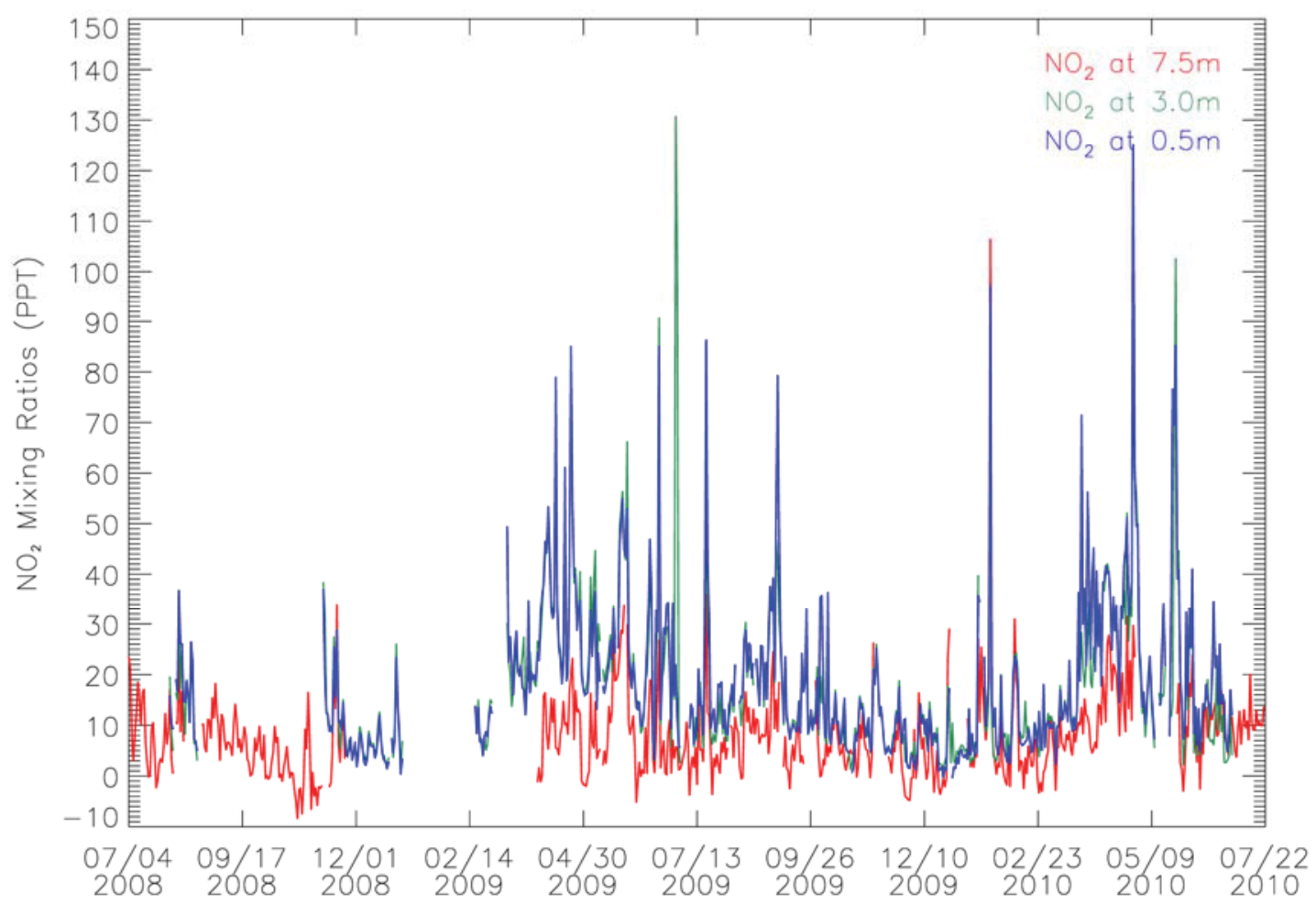

Figure 3.2. Time series of daily averaged mixing ratios of $\mathrm{NO}_{2}$ at $7.5 \mathrm{~m}, 3 \mathrm{~m}$, and $0.5 \mathrm{~m}$, respectively, above the snowpack at Summit, Greenland from July 2008 to July 2010.

In Figure 3.3 the monthly averaged $\mathrm{NO}$ at $7.5 \mathrm{~m}, 3 \mathrm{~m}$, and $0.5 \mathrm{~m}$, respectively, measured from July 2008 to July 2010 at Summit is presented. NO mixing ratios display a broad maximum above or close to $10 \mathrm{ppt}$ during months of high insolation from April to July. With the weakening of solar radiation, NO mixing ratios decrease and become stable and close to zero during polar night. Table 3.1 gives a statistical summary for the monthly averages of $\mathrm{NO}$ and $\mathrm{NO}_{2}$ from July 2008 to July 2010. As mentioned no data were recorded in the following September and October after August 2008, so NO monthly average in August might not be reliable. In consideration of this condition, NO monthly average in August 2008 was excluded when NO maximums were analyzed. Therefore, the maximums of NO monthly average at levels of $0.5 \mathrm{~m}, 3 \mathrm{~m}$, and $7.5 \mathrm{~m}$ are $16 \pm 31(1 \sigma)$ ppt in June 2009, $14 \pm 29(1 \sigma)$ ppt in June 2009, and 14 $\pm 9(1 \sigma)$ ppt in May 2009, respectively. Note maximums of monthly NO average decrease with the distance above the snowpack. 

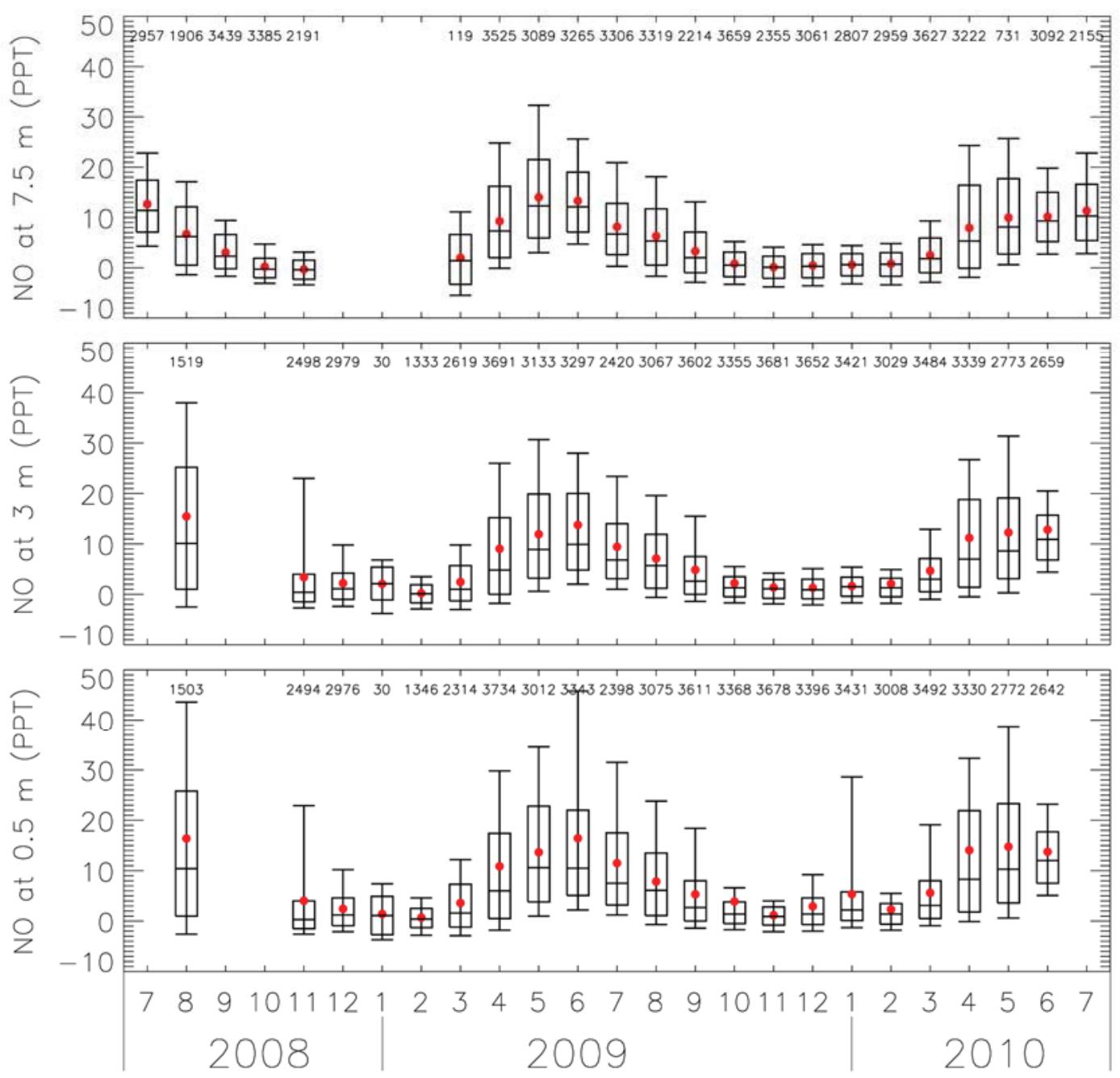

Figure 3.3. Box plots of $\mathrm{NO}$ monthly averages at $7.5 \mathrm{~m}, 3 \mathrm{~m}$, and $0.5 \mathrm{~m}$ above the snowpack at Summit from July 2008 to July 2010. The vertical whiskers represent the $5^{\text {th }}$ and $95^{\text {th }}$ percentile of the data. The box represents the middle $67 \%$ of the data. The horizontal line and red filled circle represent the median and mean of the data, respectively. The numbers at the top of each plot represent the number of data records included in the distribution.

Figure 3.4 displays statistical analyses of $\mathrm{NO}_{2}$ monthly averages measured from July 2008 to July 2010 at Summit, Greenland. It can be discovered that $\mathrm{NO}_{2}$ monthly average at 7.5 $\mathrm{m}$ is much smaller than those at $0.5 \mathrm{~m}$ and $3 \mathrm{~m}$ and that its variation is not as big as the latter ones. However, similar seasonal cycles can still be observed from the plot. Monthly $\mathrm{NO}_{2}$ mixing ratios show higher values from March to September and lower values from 
October to February of the next year. From Table 3.1 we know that the maximums of $\mathrm{NO}_{2}$ at $0.5 \mathrm{~m}, 3 \mathrm{~m}$, and $7.5 \mathrm{~m}$ occur in April 2010, April 2009, and April 2010 with mean levels of $39 \pm 39(1 \sigma) \mathrm{ppt}, 36 \pm 35(1 \sigma) \mathrm{ppt}$, and $17 \pm 14(1 \sigma) \mathrm{ppt}$, respectively.
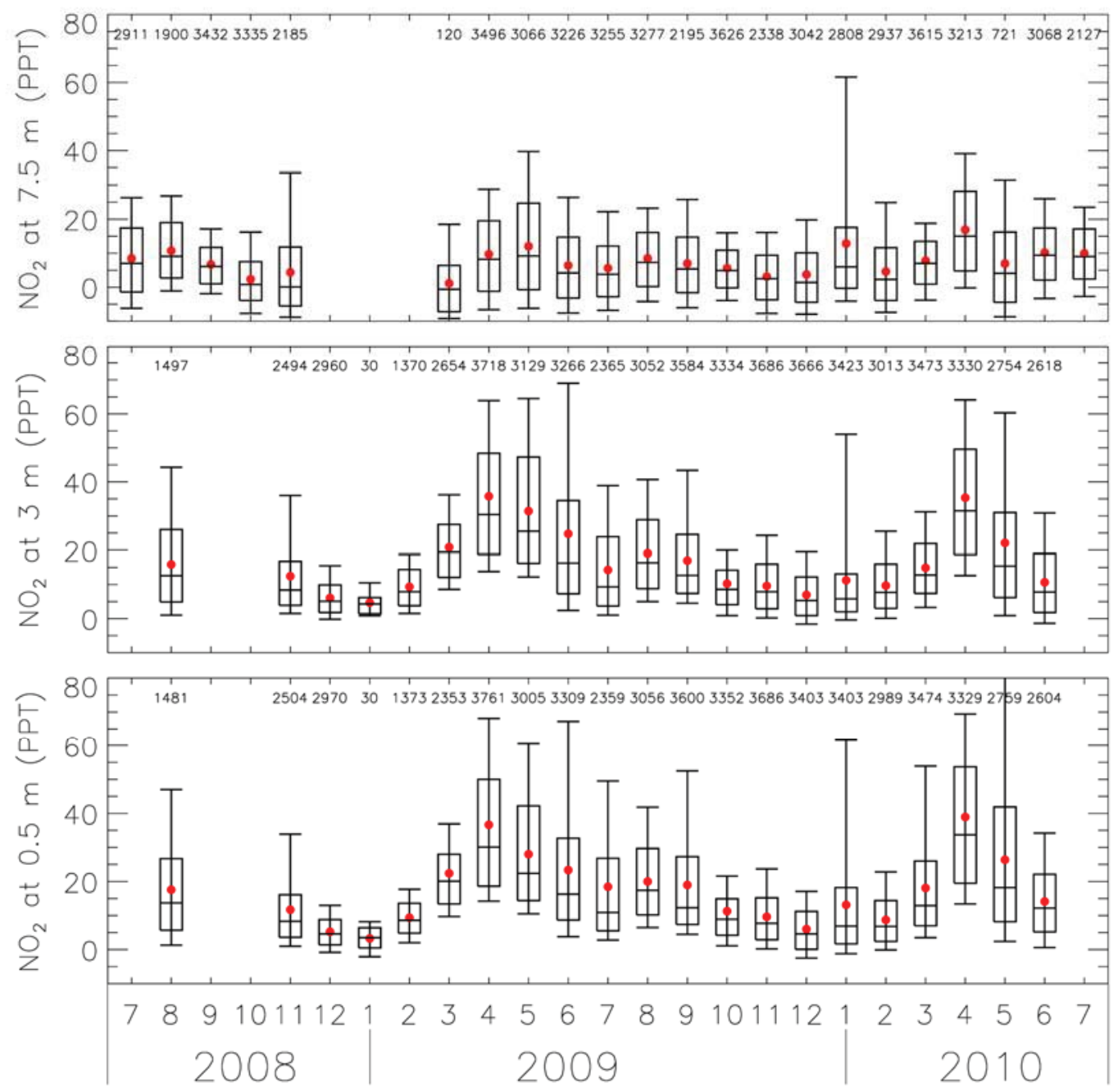

Figure 3.4. Box plots of $\mathrm{NO}_{2}$ monthly average at $7.5 \mathrm{~m}, 3 \mathrm{~m}$, and $0.5 \mathrm{~m}$ above the snowpack at Summit from July 2008 to July 2010. Horizontal lines, red filled circles, box, and numbers at the top of each plot are defined in Fig. 3.3. 
Table 3.1. Monthly statistics for $\mathrm{NO}$ and $\mathrm{NO}_{2}$ measured at Summit, Greenland from July 2008 to July 2010

\begin{tabular}{|c|c|c|c|c|c|c|c|}
\hline \multirow{2}{*}{ Year } & \multirow{2}{*}{ Month } & \multicolumn{3}{|c|}{$\mathrm{NO}(\mathrm{ppt})$} & \multicolumn{3}{|c|}{$\mathrm{NO}_{2}(\mathrm{ppt})$} \\
\hline & & $0.5 \mathrm{~m}$ & $3 \mathrm{~m}$ & $7.5 \mathrm{~m}$ & $0.5 \mathrm{~m}$ & $3 \mathrm{~m}$ & $7.5 \mathrm{~m}$ \\
\hline \multirow{6}{*}{2008} & 7 & -- & -- & $13 \pm 10$ & -- & -- & $8 \pm 13$ \\
\hline & 8 & $16 \pm 38$ & $15 \pm 27$ & $7 \pm 6$ & $18 \pm 25$ & $16 \pm 14$ & $11 \pm 9$ \\
\hline & 9 & -- & -- & $3 \pm 4$ & -- & -- & $7 \pm 6$ \\
\hline & 10 & -- & -- & $0 \pm 3$ & -- & -- & $2 \pm 8$ \\
\hline & 11 & $4 \pm 20$ & $3 \pm 13$ & $0 \pm 2$ & $12 \pm 19$ & $12 \pm 22$ & $4 \pm 16$ \\
\hline & 12 & $2 \pm 6$ & $2 \pm 7$ & -- & $5 \pm 5$ & $6 \pm 6$ & -- \\
\hline \multirow{12}{*}{2009} & 1 & $1 \pm 4$ & $2 \pm 3$ & -- & $3 \pm 3$ & $5 \pm 4$ & -- \\
\hline & 2 & $1 \pm 3$ & $0 \pm 2$ & -- & $9 \pm 7$ & $9 \pm 9$ & -- \\
\hline & 3 & $4 \pm 14$ & $2 \pm 14$ & $2 \pm 5$ & $22 \pm 32$ & $21 \pm 20$ & $1 \pm 12$ \\
\hline & 4 & $11 \pm 31$ & $9 \pm 26$ & $9 \pm 10$ & $37 \pm 41$ & $36 \pm 35$ & $10 \pm 14$ \\
\hline & 5 & $14 \pm 21$ & $12 \pm 20$ & $14 \pm 9$ & $28 \pm 23$ & $31 \pm 22$ & $12 \pm 14$ \\
\hline & 6 & $16 \pm 31$ & $14 \pm 29$ & $13 \pm 7$ & $23 \pm 29$ & $25 \pm 37$ & $6 \pm 12$ \\
\hline & 7 & $11 \pm 18$ & $9 \pm 19$ & $8 \pm 7$ & $18 \pm 30$ & $14 \pm 23$ & $6 \pm 13$ \\
\hline & 8 & $8 \pm 9$ & $7 \pm 15$ & $6 \pm 6$ & $20 \pm 13$ & $19 \pm 15$ & $8 \pm 10$ \\
\hline & 9 & $5 \pm 15$ & $5 \pm 20$ & $3 \pm 7$ & $19 \pm 26$ & $17 \pm 17$ & $7 \pm 11$ \\
\hline & 10 & $4 \pm 34$ & $2 \pm 15$ & $1 \pm 4$ & $11 \pm 27$ & $10 \pm 23$ & $6 \pm 8$ \\
\hline & 11 & $1 \pm 7$ & $1 \pm 16$ & $0 \pm 2$ & $10 \pm 19$ & $10 \pm 8$ & $3 \pm 8$ \\
\hline & 12 & $3 \pm 11$ & $1 \pm 3$ & $0 \pm 3$ & $6 \pm 11$ & $7 \pm 9$ & $4 \pm 14$ \\
\hline \multirow{7}{*}{2010} & 1 & $5 \pm 12$ & $2 \pm 2$ & $1 \pm 2$ & $13 \pm 22$ & $11 \pm 21$ & $13 \pm 12$ \\
\hline & 2 & $2 \pm 9$ & $2 \pm 8$ & $1 \pm 4$ & $9 \pm 14$ & $10 \pm 10$ & $5 \pm 12$ \\
\hline & 3 & $6 \pm 12$ & $5 \pm 10$ & $2 \pm 5$ & $18 \pm 18$ & $15 \pm 11$ & $8 \pm 11$ \\
\hline & 4 & $14 \pm 37$ & $11 \pm 28$ & $8 \pm 10$ & $39 \pm 39$ & $35 \pm 30$ & $17 \pm 14$ \\
\hline & 5 & $15 \pm 21$ & $12 \pm 20$ & $10 \pm 8$ & $26 \pm 30$ & $22 \pm 33$ & $7 \pm 15$ \\
\hline & 6 & $14 \pm 18$ & $13 \pm 25$ & $10 \pm 8$ & $14 \pm 11$ & $11 \pm 12$ & $10 \pm 9$ \\
\hline & 7 & -- & -- & $11 \pm 8$ & -- & & $10 \pm 9$ \\
\hline
\end{tabular}




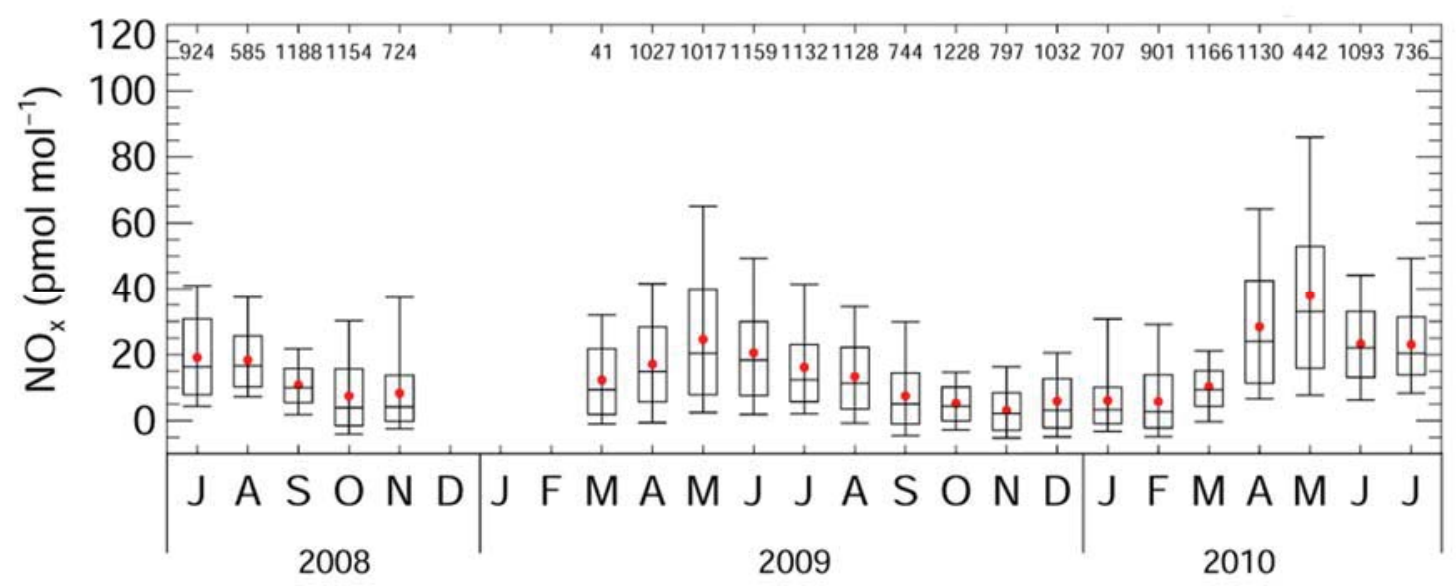

Figure 3.5. Box plots of $\mathrm{NO}_{\mathrm{x}}$ monthly average at $7.5 \mathrm{~m}$ above the snowpack at Summit from July 2008 to July 2010 (Kramer et al., 2014). Horizontal lines, red filled circles, box, and numbers at the top of each plot are defined in Fig. 3.3.

The $\mathrm{NO}_{2}$ monthly average is approximately 4 times, 5.6 times, and 3 times the magnitude of NO monthly average at $7.5 \mathrm{~m}, 3 \mathrm{~m}$, and $0.5 \mathrm{~m}$ above the snowpack, respectively. Therefore, $\mathrm{NO}_{\mathrm{x}}$ is mainly composed of $\mathrm{NO}_{2}$ at Summit. However, $\mathrm{NO}$ plays an essential role in characterizing the seasonal cycle of $\mathrm{NO}_{\mathrm{x}}$ as shown in Figure 3.5 (Kramer et al., 2014). Why does the $\mathrm{NO}_{2}$ monthly average at $3 \mathrm{~m}$ above the snowpack have a maximum of 4.6 times higher than NO monthly average at the same level? The hypothesis is that a portion of $\mathrm{NO}$ released from the snowpack is oxidized to $\mathrm{NO}_{2}$, causing $\mathrm{NO}_{2}$ to increase at $3 \mathrm{~m}$, and thereafter $\mathrm{NO}_{2}$ was diluted and mixed with ambient air as moving upward due to gradient difference. The confirmation of this hypothesis will be discussed in Section 3.2 via $\mathrm{NO}$ and $\mathrm{NO}_{2}$ gradients.

\subsection{Vertical gradients}

Monthly vertical gradients of $\mathrm{NO}$ and $\mathrm{NO}_{2}$ were calculated separately between $3 \mathrm{~m}$ and 0.5 $\mathrm{m}$, and between $7.5 \mathrm{~m}$ and $0.5 \mathrm{~m}$. In the first step, mixing ratio differences were calculated. For the mixing ratio differences between $7.5 \mathrm{~m}$ and $0.5 \mathrm{~m}$, the data at $7.5 \mathrm{~m}$ were recalculated on the time base of data at $0.5 \mathrm{~m}$ as the two sets of data had different time bases. In the second step, monthly averaged mixing ratio differences were calculated and 
plotted with box plot procedure. From Section 3.1 it is discovered that monthly averaged NO mixing ratios are very close to one another at levels of $0.5 \mathrm{~m}, 3 \mathrm{~m}$, and $7.5 \mathrm{~m}$ above the snowpack, while monthly averaged $\mathrm{NO}_{2}$ mixing ratios are more complicated than that of NO. Firstly, $\mathrm{NO}_{2}$ mixing ratios are approximately 2 to 4 times bigger than $\mathrm{NO}$ mixing ratios due to its longer lifetime in hours, more sources including PAN thermal decomposition (however, this is likely to be very limited due to low temperatures at Summit), the conversion from $\mathrm{NO}$ to $\mathrm{NO}_{2}$; Furthermore, $\mathrm{NO}_{2}$ monthly averaged mixing ratios at $7.5 \mathrm{~m}$ above the snowpack are far smaller than those at $0.5 \mathrm{~m}$ and $3 \mathrm{~m}$. That can be explained as follows: During the upward ventilation process up to approximate $7.5 \mathrm{~m}$ above the snowpack, $\mathrm{NO}_{2}$ emission from the snowpack was mixed with the ambient air and was diluted; the photolytic conversion (Reaction 1.4) may also attribute to the sink of $\mathrm{NO}_{2}$ mixing ratio. The seasonal cycles of the measured vertical gradients of $\mathrm{NO}$ and $\mathrm{NO}_{2}$ between $3 \mathrm{~m}$ and $0.5 \mathrm{~m}$ above the snowpack are shown in Figure 3.6. NO gradient between $3 \mathrm{~m}$ and $0.5 \mathrm{~m}$ is below zero during most of the time, meaning mixing ratio of $\mathrm{NO}$ is higher at $0.5 \mathrm{~m}$ than that of at $3 \mathrm{~m}$, while $\mathrm{NO}_{2}$ gradient is above zero under most circumstances, indicating mixing ratio of $\mathrm{NO}_{2}$ is higher at $3 \mathrm{~m}$ than that of at $0.5 \mathrm{~m}$. 

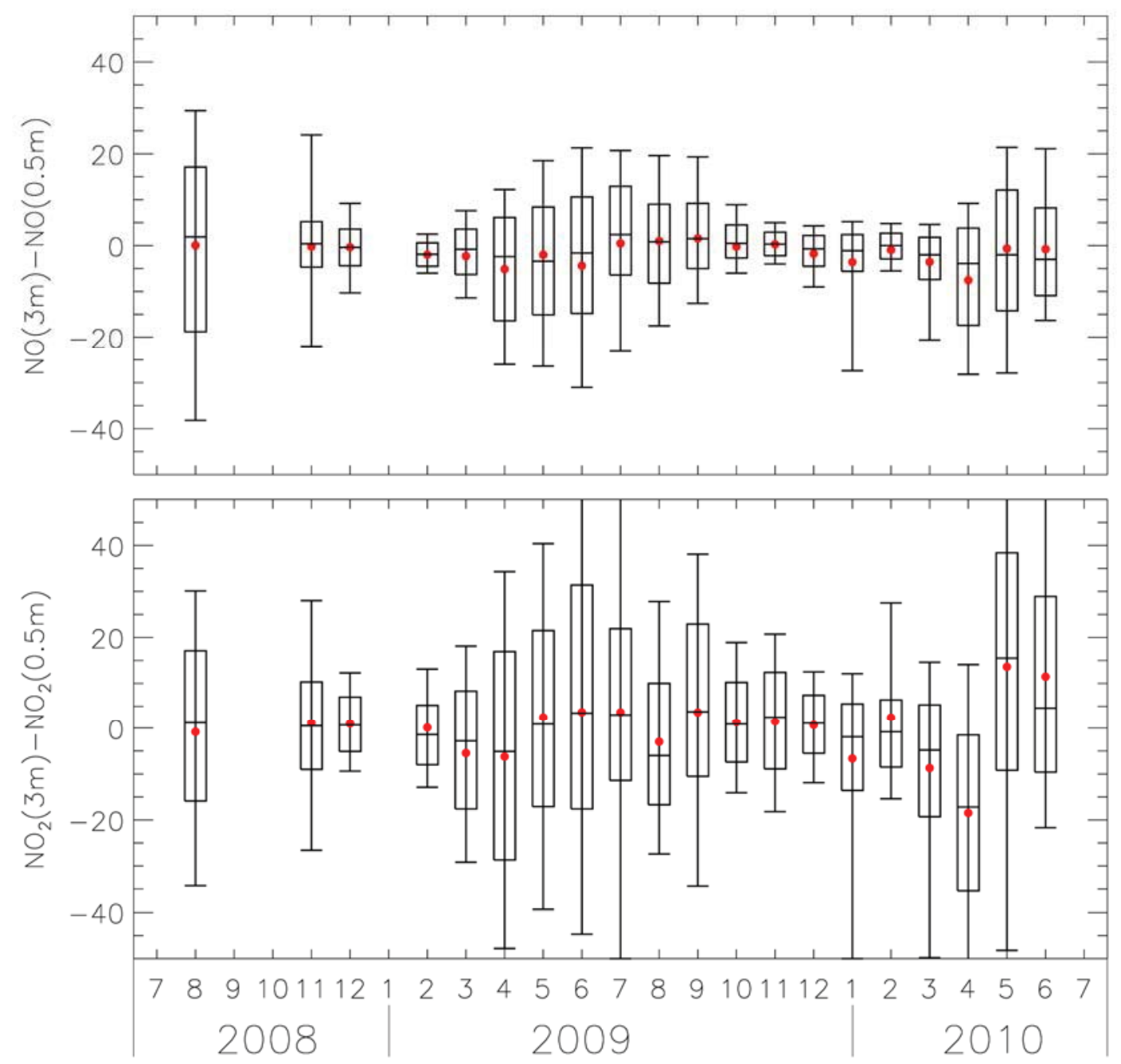

Figure 3.6. Box plots of seasonal cycles of the difference between NO monthly averaged mixing ratios at $3 \mathrm{~m}$ and $0.5 \mathrm{~m}$ (shown is $\mathrm{NO}(3 \mathrm{~m})-\mathrm{NO}(0.5 \mathrm{~m})$ ), and the difference between $\mathrm{NO}_{2}$ monthly averaged mixing ratios at $3 \mathrm{~m}$ and $0.5 \mathrm{~m}$ (shown is $\mathrm{NO}_{2}(3 \mathrm{~m})-\mathrm{NO}_{2}(0.5 \mathrm{~m})$ ).

Figure 3.7 (a) clearly displays an NO monthly average difference between $3 \mathrm{~m}$ and $0.5 \mathrm{~m}$ above the snowpack. The gradient is below or very close to zero except in July, August, and September 2009. Negative gradient from early spring to late summer suggests NO emission from the surface snowpack when solar radiation is available during the sunlight season. However, the gradients from July to September 2009 are positive due to some reasons. Solar radiation, boundary layer conditions, wind speed, and wind direction are 
likely the contributing causes. Solar radiation data from July 2008 to July 2010 did not show unusual variation during the investigated time of period. Unlike the case in south pole, $\mathrm{NO}$ and $\mathrm{NO}_{\mathrm{x}}$ concentrations do not have a clear correlation with the stable to weakly stable boundary layer in June 2010 at Summit, Greenland (Van Dam et al., 2013). Since no boundary layer depth measurements are available, it will be part of the future work to investigate the correlation between boundary layer conditions and mixing ratio variation of trace gases at Summit.
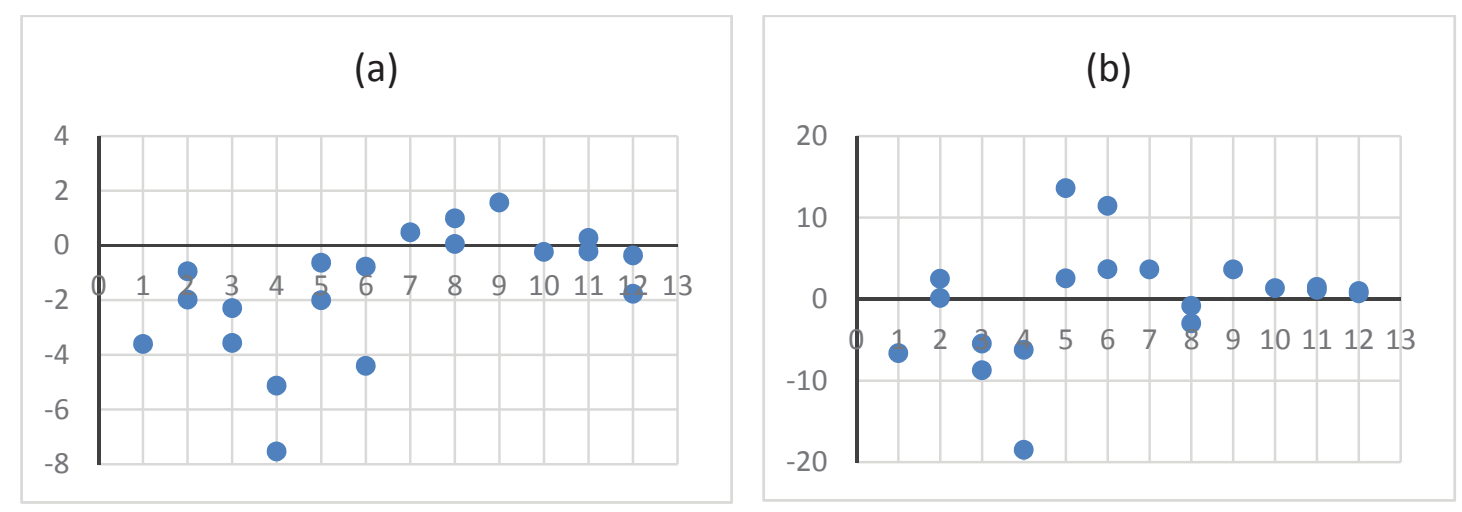

Figure 3.7 (a) NO monthly average difference between $3 \mathrm{~m}$ and $0.5 \mathrm{~m}$ above the snowpack; (b) $\mathrm{NO}_{2}$ monthly difference between $3 \mathrm{~m}$ and $0.5 \mathrm{~m}$ above the snowpack.

Wind speed plays an important part in determining mixing ratios of $\mathrm{NO}_{\mathrm{x}}$ at Summit via wind pumping and changing gas transport speed. However, wind speed data measured by NOAA at Summit did not show an obvious correlation between the wind speed from July to September 2009 and the positive gradient (Figure 3.8). 


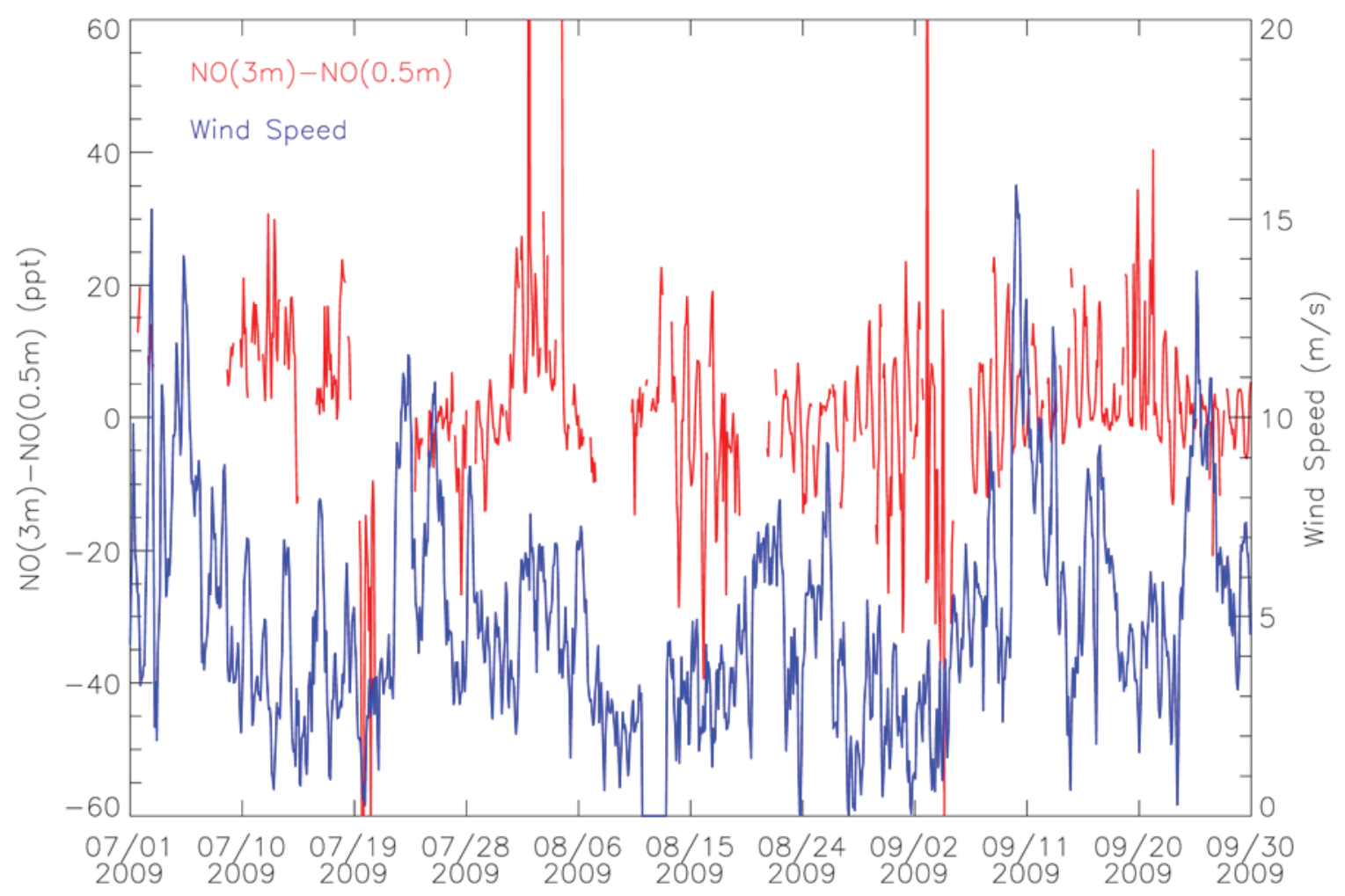

Figure 3.8. Two hours average of wind speed at Summit, Greenland from July 2009 to September 2009.

Wind direction itself has little impact on the mixing ratio of $\mathrm{NO}_{\mathrm{x}}$. However, through the air masses wind carries, wind direction can change the observed $\mathrm{NO}_{\mathrm{x}}$ mixing ratio. The measurement site is approximately $660 \mathrm{~m}$ south-west of the main camp within the "clean air" sector, where winds blow from south during most time of the year, consequently minimizing the impact from the main camp. At Summit the north winds are defined as shown in Figure 3.9, which are a bit different from the standard north winds due to the relative locations of the main camp and snow tower. If north winds occurred, local pollution could directly increase the measurements. Figure 3.10 shows the hourly wind direction from July 2009 to September 2009 at Summit. The black lines between the two red lines denote north wind occurring during the time of period. Therefore, there might be polluted air masses containing $\mathrm{NO}$ and other species transported to the measurement site. Since NO difference between $3 \mathrm{~m}$ and $0.5 \mathrm{~m}$ was very small, even small amount of NO 
source could change the gradient. Wind direction might be a contributor that cannot be ignored.

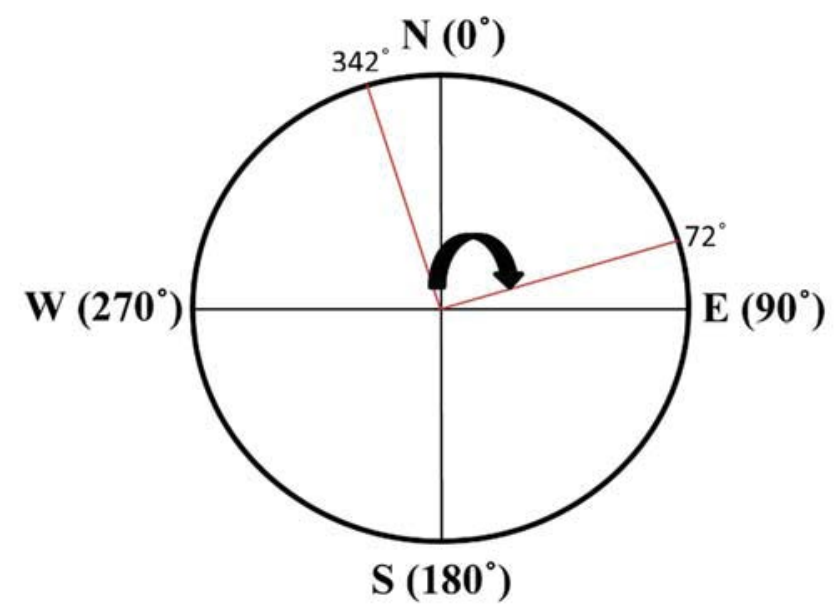

Figure 3.9. Definition of north winds at Summit, Greenland

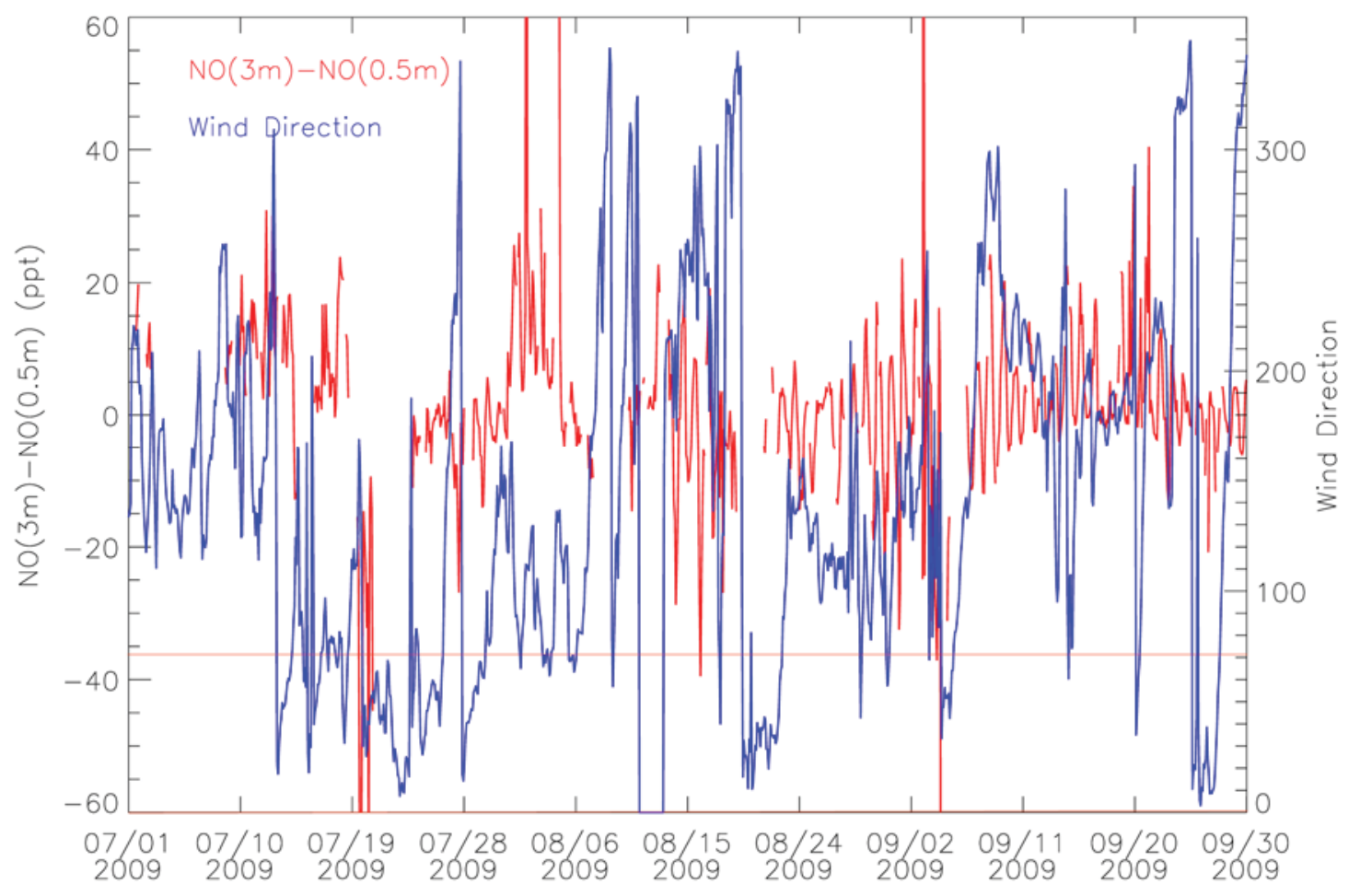

Figure 3.10. Two hours average of wind direction at Summit, Greenland from July 2009 to September 2009. 
The negative gradient of $\mathrm{NO}$ between $3 \mathrm{~m}$ and $0.5 \mathrm{~m}$ above the snowpack from early spring to late fall resulted in positive gradient of $\mathrm{NO}_{2}$ as $\mathrm{NO}$ emitted from the surface snowpack was converted to $\mathrm{NO}_{2}$. The mechanism for snowpack nitrate photolysis is discussed in Chapter 1 through the reactions below:

$$
\begin{aligned}
& \mathrm{NO}_{3}^{-}+h v \rightarrow \mathrm{NO}_{2}+\mathrm{O}^{-} \\
& \left.\mathrm{NO}_{3}^{-}+h v \rightarrow \mathrm{NO}_{2}^{-}+\mathrm{O}^{3} \mathrm{P}\right) \\
& \mathrm{NO}_{2}^{-}+h v \rightarrow \mathrm{NO}+\mathrm{O}^{-} \\
& \mathrm{NO}_{2}^{-}+\mathrm{OH} \rightarrow \mathrm{NO}_{2}+\mathrm{OH}^{-},
\end{aligned}
$$

where reaction 1.19 is more efficient than reaction 1.20 by roughly a factor of 8 to 9 from two lab experiments in aqueous phase (Warneck and Wurzinger, 1988) and on ice surfaces (Dubowski et al., 2001) and that reaction 1.21 and reaction 1.22 are two different routines following reaction 1.20 (Jacobi and Hilker, 2007; Chu and Anastasio, 2007; Grannas et al., 2007). Obviously the above mechanism does not fully work at Summit if $\mathrm{NO}_{2}$ photolysis is not considered. If reaction 1.19 driven scheme combined with reaction 1.20 driven scheme followed by reaction 1.22 (hereafter named $\mathbf{N O}_{2}$ scheme) exceeded reaction 1.20 driven scheme followed by reaction 1.21 (hereafter named NO scheme), the dominant product of $\mathrm{NO}_{3}^{-}$photolysis would be $\mathrm{NO}_{2}$, which does not agree with the positive $\mathrm{NO}_{2}$ gradient between $3 \mathrm{~m}$ and $0.5 \mathrm{~m}$ above the snowpack. It is also possible that $\mathrm{NO}_{2}$ in the snowpack originating from photolysis of nitrate during the sunlit season is subsequently photolyzed to NO. NO that is emitted from the snowpack could also be oxidized by $\mathrm{O}_{3}$ to form $\mathrm{NO}_{2}$. Due to the fact that there are no measurements of $\mathrm{NO}_{2}$ photolysis into $\mathrm{NO}$ and $\mathrm{NO}$ oxidization into $\mathrm{NO}_{2}$ at Summit during sunlit season, it is impossible to draw a conclusion here. However, the $\mathrm{NO}_{2}$ scheme is in agreement with the negative $\mathrm{NO}_{2}$ gradient in early spring (from March to April). In addition, nitrate accumulation in the snowpack through nitrate deposition during polar night season is proposed in Section 3.4, which will be re-emitted via photolysis when solar radiation is available, attributing to $\mathrm{NO}_{2}$ increase in early spring. Therefore, the proposed snowpack photochemical mechanism at Summit 
is that $\mathrm{NO}_{2}$ scheme exceeds $\mathrm{NO}$ scheme in early spring due to nitrate accumulation during polar night season and that $\mathrm{NO}$ scheme is of higher efficiency from late spring to late fall. Vertical gradients of $\mathrm{NO}_{\mathrm{x}}$ and $\mathrm{HONO}$ measured at a level of 1-2 $\mathrm{m}$ above the snowpack at Summit during summer 2000 showed that the daily average export rate of $\mathrm{NO}_{\mathrm{x}}$ emission from the snowpack is $2.52 \times 10^{12}$ molecules $\mathrm{m}^{-2} \mathrm{~s}^{-1}$ and that HONO export emission rate is $4.64 \times 10^{11}$ molecules $\mathrm{m}^{-2} \mathrm{~s}^{-1}$ (Honrath et al., 2002). So the source of $\mathrm{NO}$ emission via $\mathrm{HONO}+h v \rightarrow \mathrm{NO}+\mathrm{OH}$ should also be considered.

The seasonal cycles of $\mathrm{NO}$ and $\mathrm{NO}_{2}$ difference between $7.5 \mathrm{~m}$ and $0.5 \mathrm{~m}$ above the snowpack are displayed in Figure 3.11. From the snowpack $\mathrm{NO}_{\mathrm{x}}$ photochemical mechanism discussed above, $\mathrm{NO}$ mixing ratio is expected to decrease with the distance above the snowpack, while $\mathrm{NO}_{2}$ will increase first at around $3 \mathrm{~m}$ above the snowpack and then decrease along with the rising of distance above the snowpack, diluted and mixed with the ambient air. Additionally, the boundary layer variations might impact the mixing ratios of $\mathrm{NO}$ and $\mathrm{NO}_{2}$. Typically the boundary layer is stable, but when the radiation changes diurnally, for example, in spring, the warming of the surface can result in the boundary layer height increasing, which will then dilute any gases in the boundary layer like $\mathrm{NO}_{\mathrm{x}}$. Therefore, both $\mathrm{NO}$ gradient and $\mathrm{NO}_{2}$ gradient between $7.5 \mathrm{~m}$ and $0.5 \mathrm{~m}$ are tending to be below zero due to the gas dispersion process. 

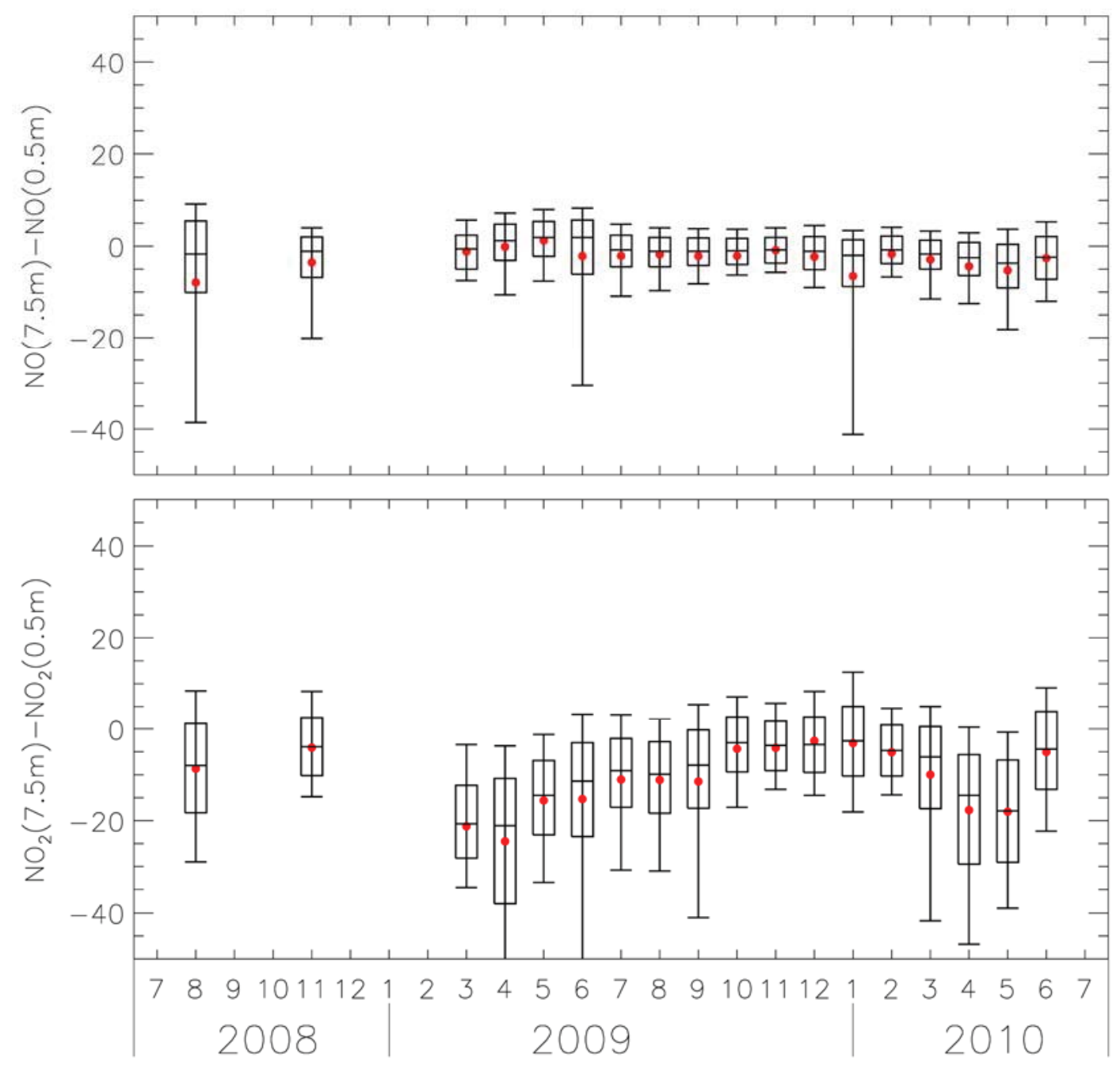

Figure 3.11. Box plots of seasonal cycles of the difference between NO monthly averaged mixing ratios at $7.5 \mathrm{~m}$ and $0.5 \mathrm{~m}$ (shown is $\mathrm{NO}(7.5 \mathrm{~m})-\mathrm{NO}(0.5 \mathrm{~m})$ ), and the difference between $\mathrm{NO}_{2}$ monthly averaged mixing ratios at $7.5 \mathrm{~m}$ and $0.5 \mathrm{~m}$ (shown is $\mathrm{NO}_{2}(7.5 \mathrm{~m})-\mathrm{NO}_{2}(0.5 \mathrm{~m})$ ). 

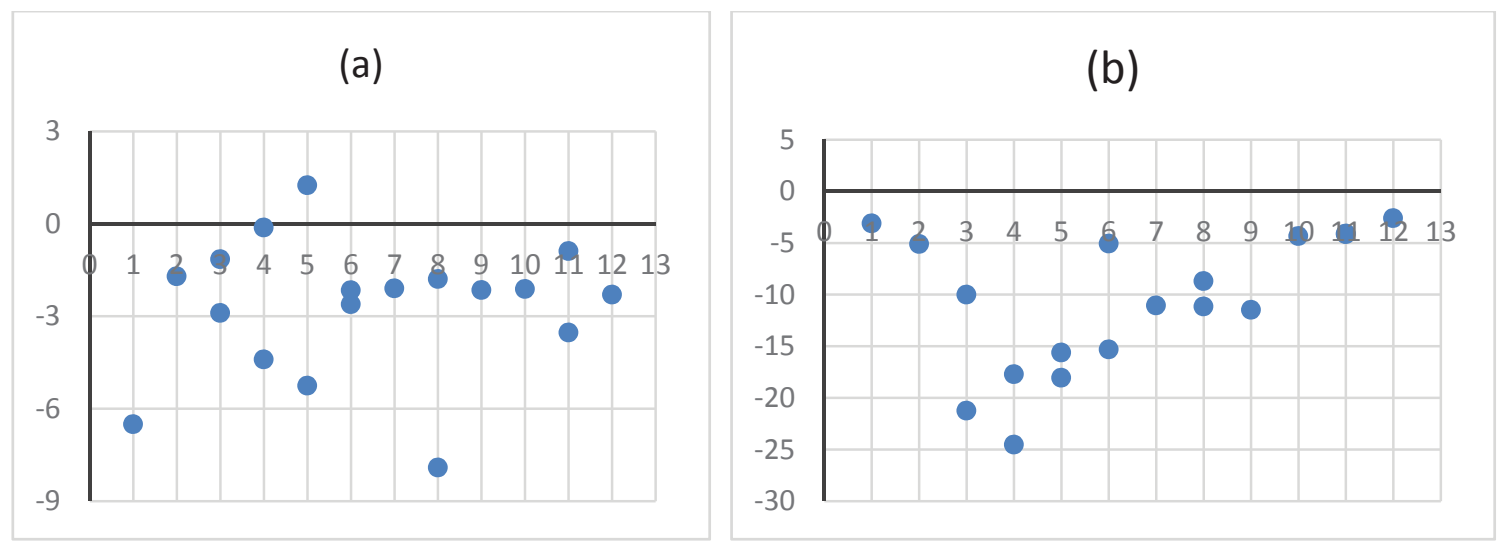

Figure 3.12 (a) NO monthly average difference between $7.5 \mathrm{~m}$ and $0.5 \mathrm{~m}$ above the snowpack; (b) $\mathrm{NO}_{2}$ monthly average difference between $7.5 \mathrm{~m}$ and $0.5 \mathrm{~m}$ above the snowpack.

Figure 3.12 (a) and (b) displayed $\mathrm{NO}$ and $\mathrm{NO}_{2}$ monthly difference between $7.5 \mathrm{~m}$ and 0.5 m above the snowpack, respectively. We notice NO difference is positive in May 2009, which should be negative if no NO source is transported to the measurement site. Pollution events are identified with FLEXPART retroplume analyses in Section 3.4. Anthropogenic event 41 to 45 and fire event 6 occurred in May, which are the likely contributors to the NO increase at $7.5 \mathrm{~m}$ above the snowpack. Long range transported pollution to the site from North America and Europe and stratosphere-troposphere exchange might contribute to the gradient enhancements. That is different from the gradients between $3 \mathrm{~m}$ and $0.5 \mathrm{~m}$, which is mainly driven by snowpack nitrate photolysis. 


\subsection{Diurnal cycles}

Since $\mathrm{NO}$ and $\mathrm{NO}_{2}$ are mainly produced via nitrate photochemical reactions, it is expected that $\mathrm{NO}$ and $\mathrm{NO}_{2}$ vary diurnally with sunlight intensity. Here diurnal variability of $\mathrm{NO}$ and $\mathrm{NO}_{2}$ was investigated in March, April, May, and June from 2009 to 2010 (no data from March to June in 2008) separately when solar radiation is available at Summit. The analysis gives information about the patterns of diurnal cycles for $\mathrm{NO}$ and $\mathrm{NO}_{2}$ in sunlight season.

Figure 3.13 shows diurnal cycles of $\mathrm{NO}$ at levels of $7.5 \mathrm{~m}, 3 \mathrm{~m}$, and $0.5 \mathrm{~m}$ above the snowpack from March to June during the measurement period. Each box represents 2-hour average of the data measured during each time of the day. The time is shown as UTC with local noon corresponding to approximate $3 \mathrm{PM}$. The mean and median are close to each other under most circumstances, but they are usually not at the middle of the data, which indicates that the data are not evenly distributed but clustering at either ends (Toro, 2011). Under the circumstance that the mean is far larger than the median, the data are clustered at high values, indicating occurrence of likely enhancements.

Apparent diurnal cycles were observed with high values around local noon, exactly following the solar radiation variation and also consistent with the expectation that $\mathrm{NO}$ is the product of nitrate photolysis within the snowpack (Toro, 2011; Honrath et al., 2002). The diurnally varying boundary layer depth may also have an impact on the diurnal cycles. Prior study showed the boundary layer depth in June 2010 was not an important factor in determining the levels of trace gases like at South Pole, but it is still an influential factor. More investigations should be conducted. Note NO diurnal cycle in June is anomalous compared to those in March, April, and May. The enhancement from the $18^{\text {th }}$ to $24^{\text {th }}$ hour might be the cause. The values at the $95^{\text {th }}$ percentile are 57,67, and 58, respectively, for the three boxes, which are not shown in the plot due to y-axis range limitation. It indicates, combined with the larger difference between the mean and median, that there is a greater amount of outliers during that time of the day in June. Under such circumstance, if median is chosen instead of mean to display the diurnal cycle, however, a similar cycle can still be 
observed. The gradients of NO are similar to what is discussed in Section 3.2 in the corresponding months.
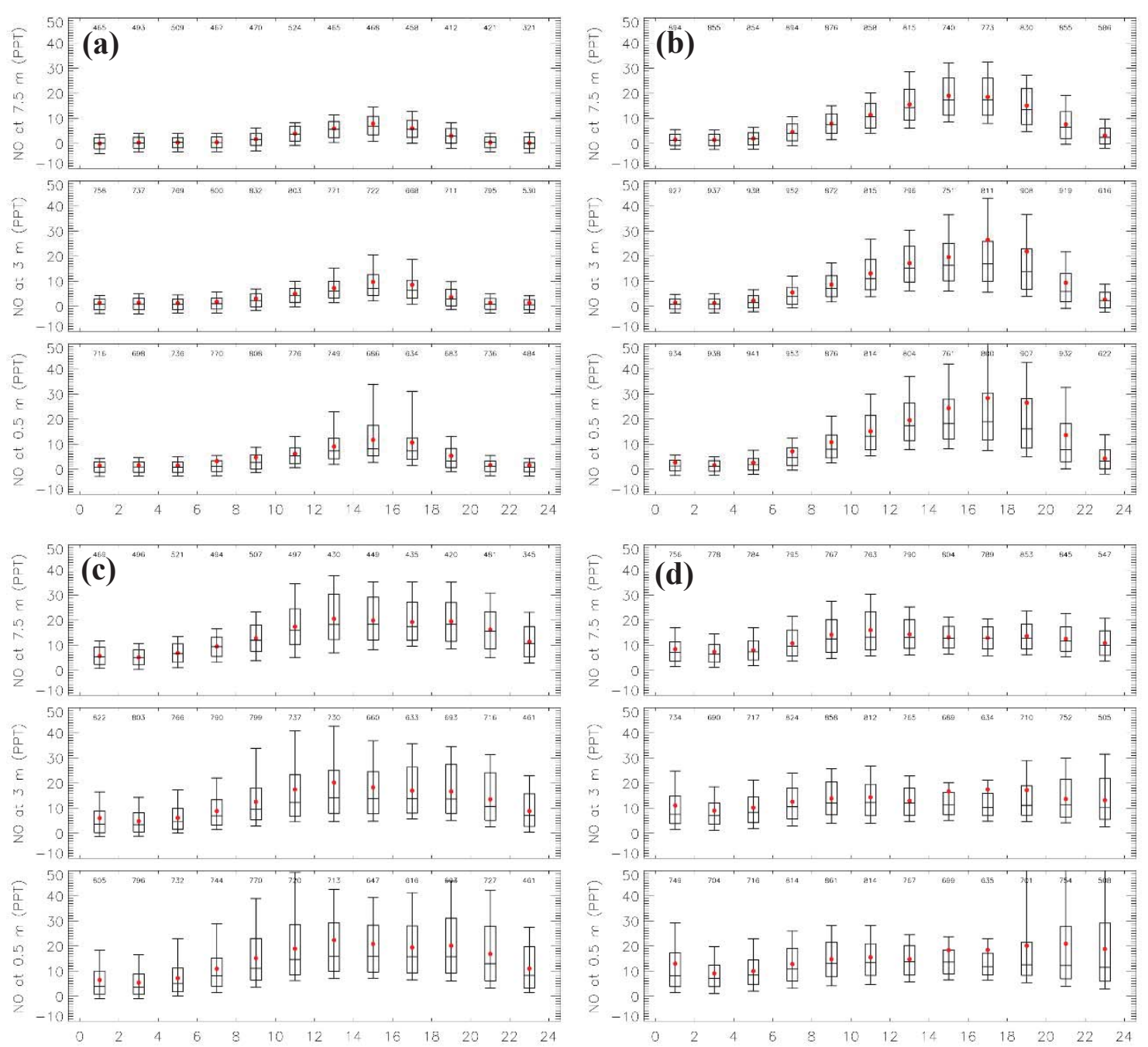

Figure 3.13. Box plots of NO average diurnal cycles for the months of March (a), April (b), May (c), and June (d) from 2009 to 2010 (no data from March to June in 2008) 7.5m, 3 m, and $0.5 \mathrm{~m}$ above the snowpack at Summit. The vertical whiskers represent the $5^{\text {th }}$ and $95^{\text {th }}$ percentile of the 2hour average of all the data. The box represents the middle $67 \%$ of the data. The horizontal line and red circle represent the median and mean of the data, respectively. The time is shown as local time (UTC) with local noon corresponding to approximate 3 PM. 

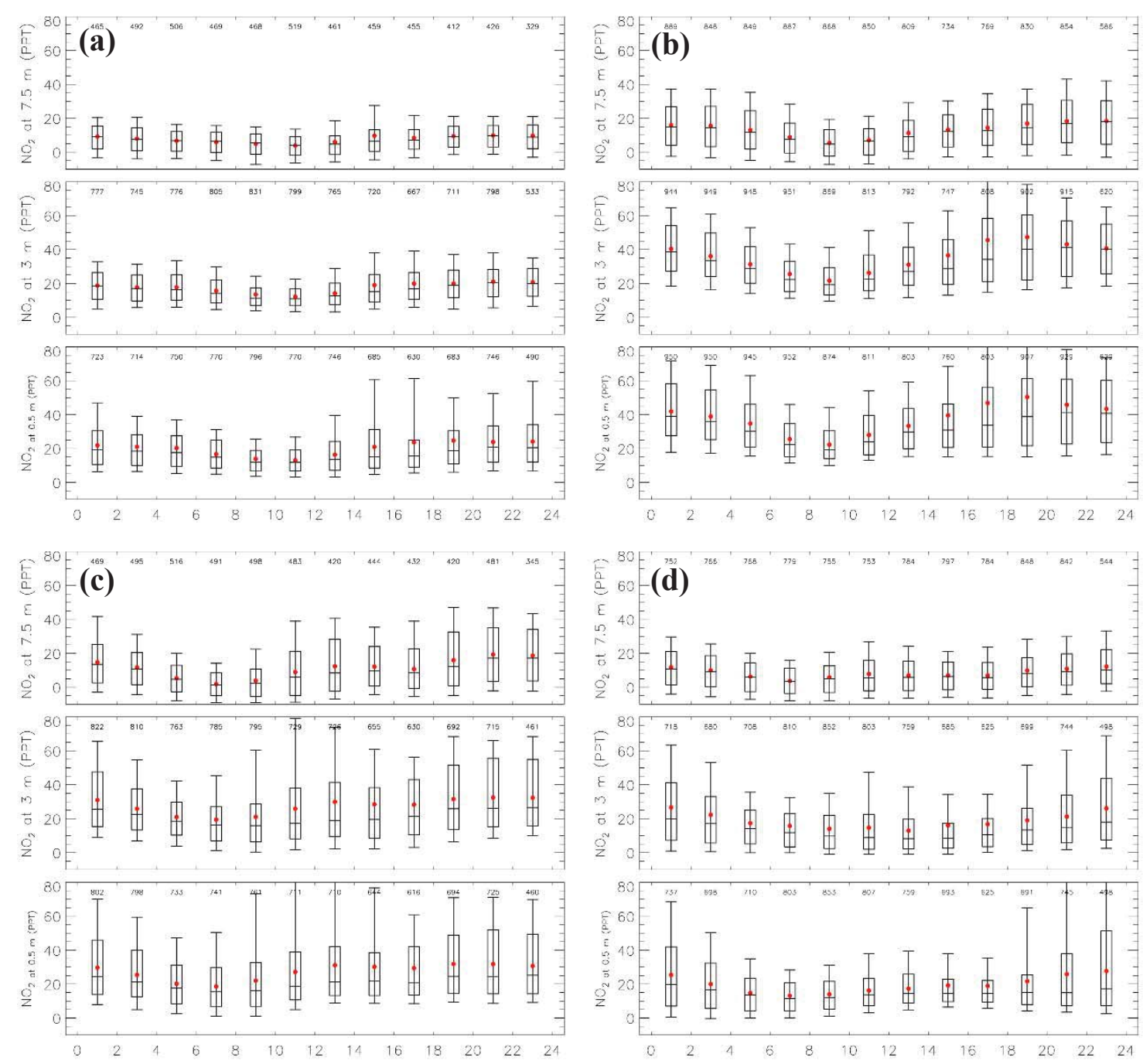

Figure 3.14. Box plots of $\mathrm{NO}_{2}$ average diurnal cycles for the months of March (a), April (b), May (c), and June (d) from 2009 to 2010 (no data from March to June in 2008) 7.5m, $3 \mathrm{~m}$, and $0.5 \mathrm{~m}$ above the snowpack at Summit. The description is similar to Figure 3.13.

The diurnal cycle for $\mathrm{NO}_{2}$ is displayed in Figure 3.14. Still take the case at $0.5 \mathrm{~m}$ above the snowpack for example, obvious diurnal cycles can be observed except in June with higher values in the afternoon and lower values in early morning till noon. April is the month when $\mathrm{NO}_{2}$ reaches highest values, which was discussed in Section 3.1. Average mixing ratios of $\mathrm{NO}_{2}$ started to increase from local noon (3 PM) and reached maximums at $5 \mathrm{PM}$, while it is at local noon that NO reached its maximums. Therefore, NO is expected to have 
an important impact on $\mathrm{NO}_{2}$. In June, $\mathrm{NO}_{2}$ is as anomalous as $\mathrm{NO}$ and the diurnal cycle is very weak, which might be caused by enhancement or decreased solar radiation.

\subsection{Event analysis}

The short term peaks in Figure 3.1 and Figure 3.2 and the positively skewed whiskers in the box plots indicate that the measurement site was often impacted by external pollutions transported from lower latitudes and in consequence air masses containing high levels of nitrogen species were sampled year-round (Kramer et al., 2014). Here a short term peak with elevated levels of $\mathrm{NO}$ or $\mathrm{NO}_{2}$ is defined as an event when anthropogenic emission tracer $\mathrm{BC}_{\text {anthro }}$ is larger than $75^{\text {th }}$ percentile of the total $\mathrm{BC}_{\text {anthro }}$ and lasts for at least 12 hours during the measurement period, or when biomass burning emission tracer $\mathrm{BC}_{\text {fire }}$ is greater than $90^{\text {th }}$ percentile of the total $\mathrm{BC}_{\text {fire }}$ (Kramer et al., 2014). The former criteria corresponds to $\mathrm{BC}_{\text {anthro }}>0.082 \mathrm{ppt}$ and the latter corresponds to $\mathrm{BC}_{\text {fire }}>7 \mathrm{ppt}$. There are 85 anthropogenic events (Table 3.2) and 13 biomass burning events (Table 3.3) in total that were identified with FLEXPART retroplume analyses under the previous criterion during the whole measurement period from July 2008 to July 2010 (Kramer et al., 2014). 
Table 3.2. Statistics of start date, event length, $\mathrm{BC}_{\mathrm{anthr}}$, plume age, and source for a part of anthropogenic events identified with FLEXPART (Kramer et al., 2014).

\begin{tabular}{|c|c|c|c|c|c|}
\hline Event & Start Date & $\begin{array}{l}\text { Event Length } \\
\text { (h) }\end{array}$ & $\begin{array}{c}\mathrm{BC}_{\text {anthro }} \\
(\mathrm{ppt})\end{array}$ & $\begin{array}{l}\text { Plume Age } \\
\text { (days) }\end{array}$ & Source $^{b}$ \\
\hline 1 & $07 / 04 / 2008$ & 12 & 0.012 & 8 & EU \\
\hline 2 & $07 / 05 / 2008$ & 21 & 0.017 & 9 & EU \\
\hline 3 & $07 / 28 / 2008$ & 18 & 0.025 & 9 & EU \\
\hline 4 & 07/29/2008 & 66 & 0.023 & 10 & EU \\
\hline 5 & $08 / 02 / 2008$ & 18 & 0.011 & 12 & EU \\
\hline 6 & $09 / 01 / 2008$ & 27 & 0.023 & 7 & EU \\
\hline 7 & $09 / 12 / 2008$ & 51 & 0.016 & 9 & EU \\
\hline 8 & $10 / 09 / 2008$ & 54 & 0.017 & 11 & NA \\
\hline-- & --- & -- & -- & -- & -- \\
\hline 16 & $11 / 18 / 2008$ & 18 & 0.051 & 9 & NA \\
\hline-- & --- & -- & -- & -- & -- \\
\hline 45 & 05/27/2009 & 21 & 0.014 & 15 & $\mathbf{E U}$ \\
\hline-- & --- & -- & -- & -- & -- \\
\hline 70 & $01 / 22 / 2010$ & 33 & 0.053 & 8 & $\mathbf{E U}$ \\
\hline 78 & $03 / 14 / 2010$ & 81 & 0.015 & 12 & EU \\
\hline 79 & $03 / 20 / 2010$ & 18 & 0.013 & 13 & EU \\
\hline 80 & $03 / 30 / 2010$ & 18 & 0.013 & 14 & EU \\
\hline 81 & $04 / 02 / 2010$ & 33 & 0.012 & 15 & EU \\
\hline 82 & $04 / 03 / 2010$ & 24 & 0.015 & 14 & $\mathrm{EU}$ \\
\hline 83 & 04/07/2010 & 18 & 0.013 & 11 & EU \\
\hline 84 & $05 / 11 / 2010$ & 15 & 0.022 & 7 & NA \\
\hline 85 & $05 / 18 / 2010$ & 51 & 0.014 & 12 & $\mathrm{EU}$ \\
\hline
\end{tabular}

${ }^{a}$ represents mean weighted age from FLEXPART;

${ }^{\mathrm{b}}$ represents primary anthropogenic emission source. $\mathrm{NA}=$ North America, EU=Europe, $\mathrm{AS}=\mathrm{Asia}$. 
Table 3.3. Statistics of start date, event length, $\mathrm{BC}_{\text {fire, }}$ plume age, and source for biomass burning events identified with FLEXPART (Kramer et al., 2014).

\begin{tabular}{lccccc}
\hline Event & Start Date & $\begin{array}{c}\text { Event Length } \\
(\mathrm{h})\end{array}$ & $\begin{array}{c}\text { BC }_{\text {fire }} \\
(\mathrm{ppt})\end{array}$ & $\begin{array}{c}\text { Plume Age }^{\mathrm{a}} \\
(\text { days })\end{array}$ & Source $^{\mathrm{b}}$ \\
\hline 1 & $07 / 25 / 2008$ & 33 & 30.6 & 9 & $\mathrm{NA}$ \\
2 & $08 / 01 / 2008$ & 15 & 25.0 & 15 & $\mathrm{NA}$ \\
3 & $08 / 03 / 2008$ & 252 & 90.7 & 14 & $\mathrm{NA}$ \\
4 & $03 / 15 / 2009$ & 60 & 58.6 & 12 & $\mathrm{EU}$ \\
5 & $03 / 18 / 2009$ & 33 & 23.1 & 15 & EU \\
6 & $03 / 21 / 2009$ & 21 & 17.6 & 16 & $\mathrm{EU}$ \\
$\mathbf{7}$ & $\mathbf{0 5 / 2 7 / 2 0 0 9}$ & $\mathbf{3 0}$ & $\mathbf{1 7 . 7}$ & $\mathbf{1 6}$ & AS \\
8 & $07 / 17 / 2009$ & 12 & 19.9 & 13 & $\mathrm{NA}$ \\
9 & $07 / 18 / 2009$ & 15 & 13.5 & 14 & $\mathrm{NA}$ \\
10 & $08 / 16 / 2009$ & 18 & 11.8 & 18 & $\mathrm{NA}$ \\
11 & $08 / 18 / 2009$ & 12 & 9.5 & 17 & $\mathrm{NA}$ \\
12 & $06 / 07 / 2010$ & 27 & 11.3 & 13 & NA \\
13 & $07 / 18 / 2010$ & 51 & 27.4 & 9 & NA \\
\hline
\end{tabular}

${ }^{a}$ represents mean weighted age from FLEXPART;

${ }^{\mathrm{b}}$ represents primary $\mathrm{BB}$ source. $\mathrm{NA}=$ North America, $\mathrm{EU}=$ Europe, $\mathrm{AS}=\mathrm{Asia}$.

All anthropogenic and biomass burning events were investigated visually. Besides the missing data mentioned in Section 3.1, there are additionally some small gaps within the observed $\mathrm{NO}$ and $\mathrm{NO}_{2}$ data due to transient instrument malfunctions or power outage at the station, which happened to be located within the event periods, leading to that many events are hard to analyze. For anthropogenic events, 33 out of 85 have no or only have limited corresponding $\mathrm{NO}$ and $\mathrm{NO}_{2}$ data. For biomass burning events, it is 4 out of 13 . In consequence, $38 \%$ in total of the events do not have sufficient corresponding data. Besides, the length of a portion of events lasts for days, causing the long range transported pollution from lower latitudes mixed together with snowpack photolysis emissions. Under this circumstance it is impossible to investigate the variations of $\mathrm{NO}$ and $\mathrm{NO}_{2}$ before, during, and after the event with the dataset available. In summary, 20 anthropogenic events and 3 biomass burning event last for over approximate 2-3 days, which account for $23 \%$ of the total events. Furthermore, limited quantities of the events are not in agreement with FLEXPART simulations like anthropogenic event 52 and 53 probably due to missing BC tracer in FLEXPART. The remaining events still have a big problem that most of the events 
are composed of a series of small events, making it hard to track the exact source of the transported emissions.

Due to the above challenges, only three events are selected to investigate what happened during an event. Figure 3.15 and Figure 3.16 showed two anthropogenic events during the polar night season when sunlight is limited. The anthropogenic tracer $\mathrm{BC}_{\text {anthro }}$ from FLEXPART retroplume simulations is in agreement with the observed $\mathrm{NO}$ and $\mathrm{NO}_{2}$ data. When the anthropogenic pollution is transported to the site, $\mathrm{NO}_{2}$ and $\mathrm{NO}_{\mathrm{y}}$ mixing ratios were elevated quickly and reached their maximums. As the pollution was transported out of the site, the mixing ratios of the above species decreased and returned to a level close to that before the event. The event has a direct impact on the $\mathrm{NO}_{2}$ gradients, which might imply the height of the transport pathways and its variations. 


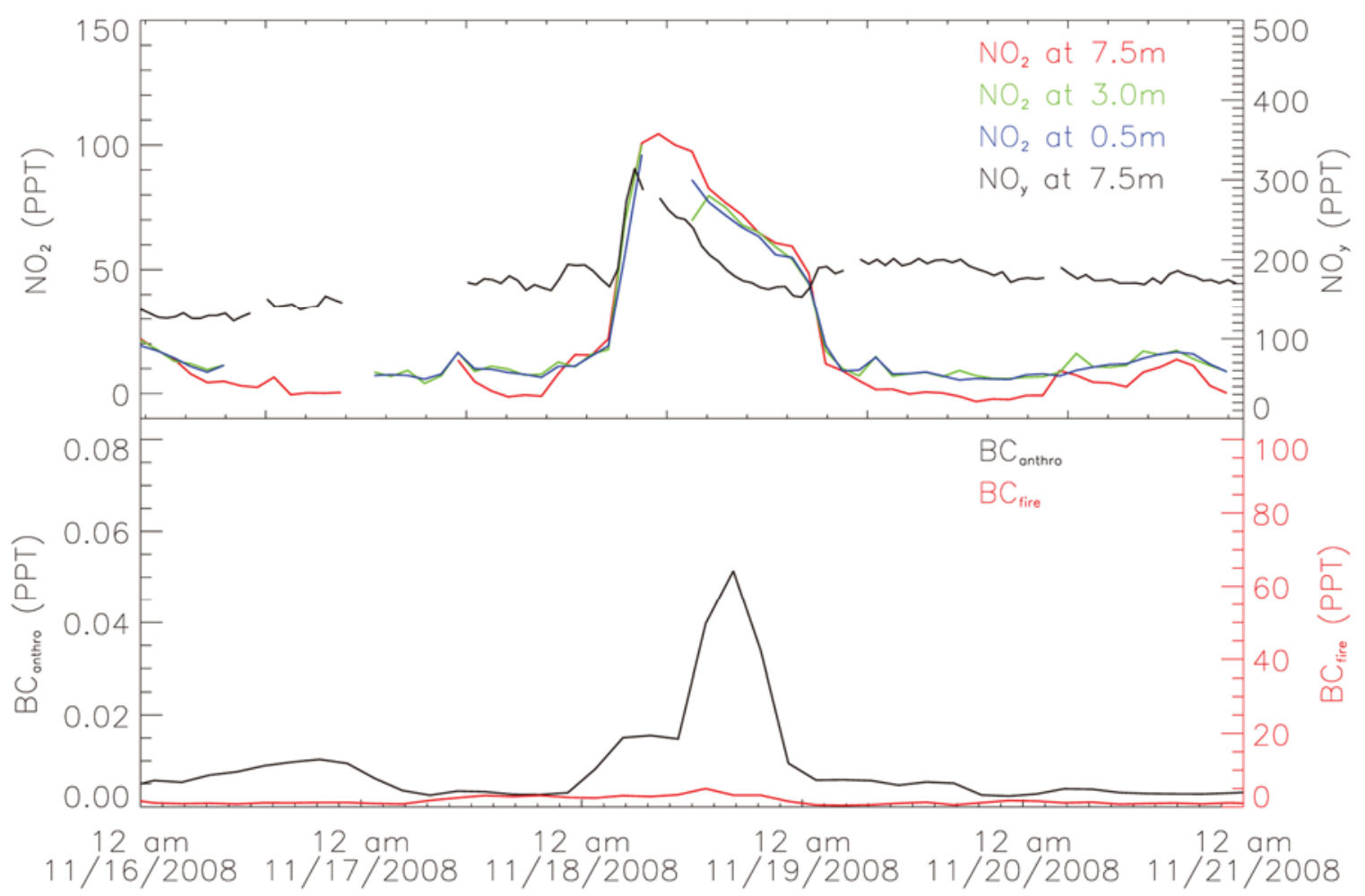

Figure 3.15. Anthropogenic event 16 identified with FLEXPART is in agreement with the observed data. The upper plot displays the hourly averaged mixing ratios of $\mathrm{NO}_{2}$ at levels of $7.5 \mathrm{~m}$, $3 \mathrm{~m}$, and $0.5 \mathrm{~m}$, and $\mathrm{NO}_{\mathrm{y}}$ at a level of $7.5 \mathrm{~m}$ above the snowpack. The bottom plot shows FLEXPART simulated anthropogenic emission tracer $\mathrm{BC}_{\text {anthro }}$ and biomass burning emission tracer $\mathrm{BC}_{\text {fire. }}$. 


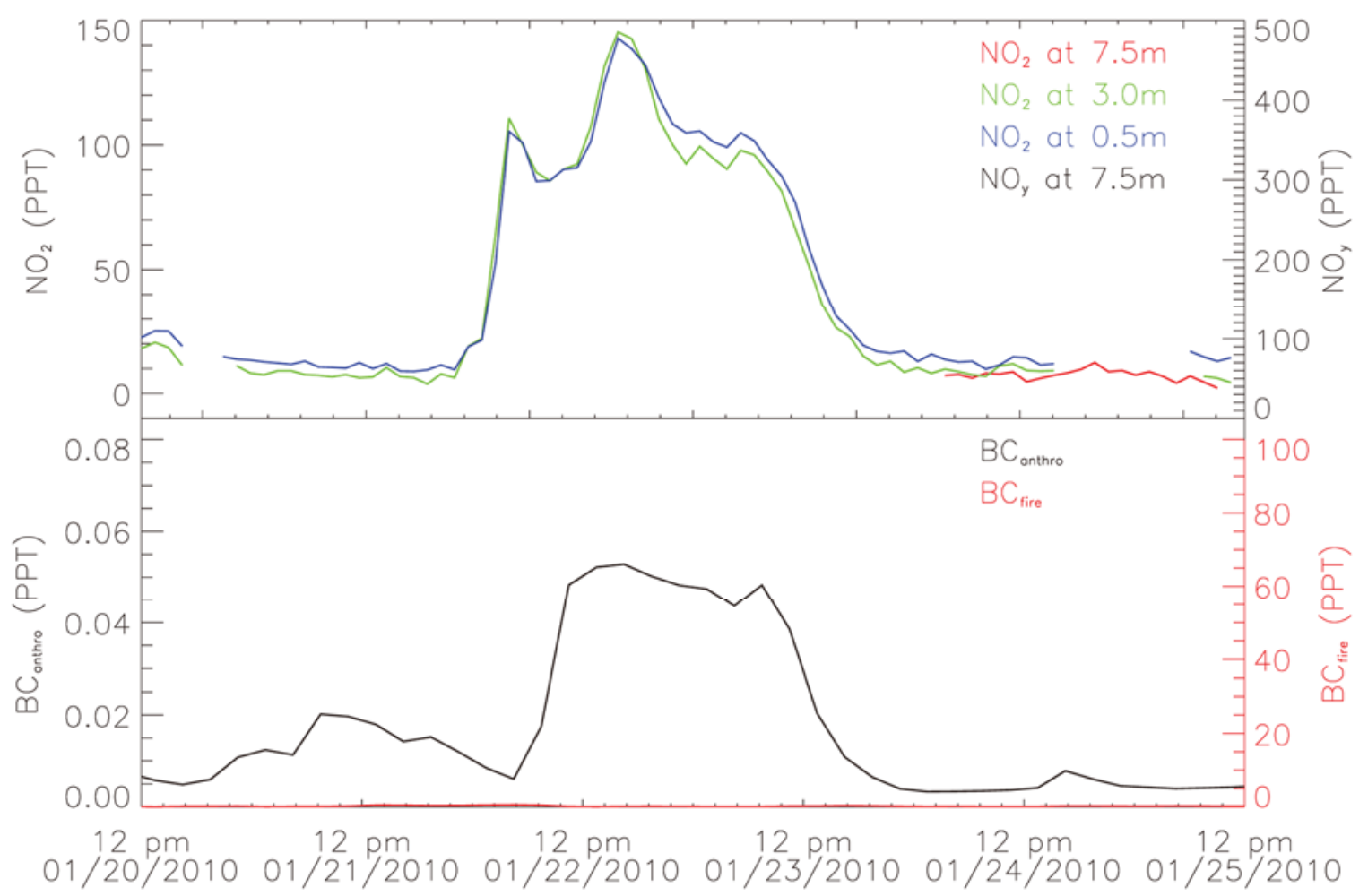

Figure 3.16. Anthropogenic event 70 identified with FLEXPART is well in agreement with the observed data. All symbols and definitions are same as Figure 3.15.

NO mixing ratio variations during the anthropogenic events were also investigated as shown in Figure 3.17. It can be seen that anthropogenic events have very limited impact on the NO mixing ratios (close to zero during the time period) during polar night season, which implies the anthropogenic emissions contain very limited NO. It is also possible that the boundary layer was very low during polar nights in winter and the anthropogenic transported emissions did not mix with the boundary layer, and therefore were not measured. Anthropogenic event 70 is solely controlled by anthropogenic emission, while biomass burning emission partially has an impact on anthropogenic event 16, which explains the small variation of NO during the event. Actually most of the anthropogenic pollution events occurring in summertime are a mixture of anthropogenic emissions and biomass burning emissions. 

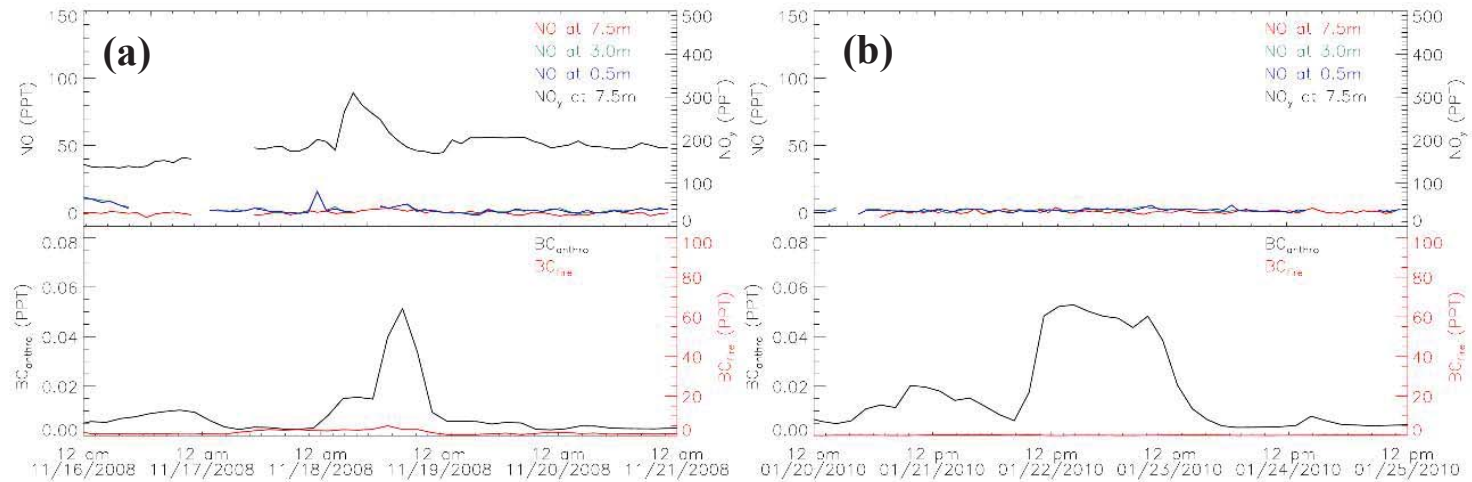

Figure 3.17. (a) NO mixing ratio variations during anthropogenic event 16; (b) NO mixing ratio variations during anthropogenic event 70 .

Figure 3.18 represents an event that was impacted by both anthropogenic emissions and biomass burning emissions during summertime 2009. It is identified as anthropogenic event 45 and biomass burning event 7 by FLEXPART retroplume analysis, which is more complicated than the previous two events occurring during polar night season. Both anthropogenic emissions and biomass burning emissions impacted on the variation of $\mathrm{NO}_{2}$. Furthermore, nitrate snowpack emission, $\mathrm{HNO}_{3}$ deposition and re-emission also contribute to the variation (Honrath et al., 2002). Here it is not possible to quantify the contributions that the contributors made to the variation of $\mathrm{NO}_{\mathrm{x}}$ with the current data available. However, it is possible to show something about the deposition and re-emission of nitrate.

The events shown in Figure 3.15 and Figure 3.16 indicate that $\mathrm{NO}_{2}$ mixing ratios are highly elevated during the events but returned to previous levels after the events. Furthermore, no subsequent $\mathrm{NO}_{2}$ increase is observed that is directly relevant to the disappeared events. However, $\mathrm{NO}_{2}$ mixing ratios in Figure 3.18 were observed to increase 2 days after the event and far exceeded the levels before the event. The subsequent $\mathrm{NO}_{2}$ increase can be explained by $\mathrm{NO}_{2}$ emission from the snowpack. Vertical fluxes of $\mathrm{NO}_{x}, \mathrm{HONO}$, and $\mathrm{HNO}_{3}$ above the snowpack measured during summer 2010 at Summit showed that daily average of upward fluxes of $\mathrm{NO}_{x}$ and $\mathrm{HONO}(\mathrm{HONO}+h v \rightarrow \mathrm{NO}+\mathrm{OH})$ was larger than that of $\mathrm{HNO}_{3}$ deposition by 3.5 times (Honrath et al., 2002). Therefore, it is possible that $\mathrm{NO}_{2}$ was deposited to the snowpack during the event and re-emitted from snowpack after the event 
via nitrate photolysis, which contributed the subsequent peaks. The above explanation is based on the assumption that FLEXPART retroplume simulations are reliable. There is possibility that the subsequent peak was due to another pollution event, which FLEXPART simulation failed to identify. In addition, pre-existing snowpack emission, wind pumping may also be the contributors to the subsequent peaks. It is impossible to determine an exact reason for the peak with current available data. More work needs to be done to investigate this event.

Depending on the weather conditions, $\mathrm{NO}_{2}$ can be deposited to the snowpack by dry deposition or/and wet deposition. Since snowfall is very limited at Summit, dry decomposition is expected to prevail over wet deposition during most time of the year. The deposition process plays a role in altering the gradient of $\mathrm{NO}_{2}$. During a "pure" dry decomposition process without post-depositional emissions from the snowpack, $\mathrm{NO}_{2}$ gradient is expected to be negative. Before the anthropogenic event 70 as shown in Figure 3.18 , the mixing ratio of $\mathrm{NO}_{2}$ was smaller at $3 \mathrm{~m}$ than at $0.5 \mathrm{~m}$. As the anthropogenic emission was being transporting to the site, $\mathrm{NO}_{2}$ at $3 \mathrm{~m}$ became larger than at $0.5 \mathrm{~m}$. At the end stage of the event after the peak, dry decomposition occurred and caused $\mathrm{NO}_{2}$ at $0.5 \mathrm{~m}$ became larger than $3 \mathrm{~m}$. Therefore, both transported emissions and deposition process can impact the gradient of $\mathrm{NO}_{2}$. 


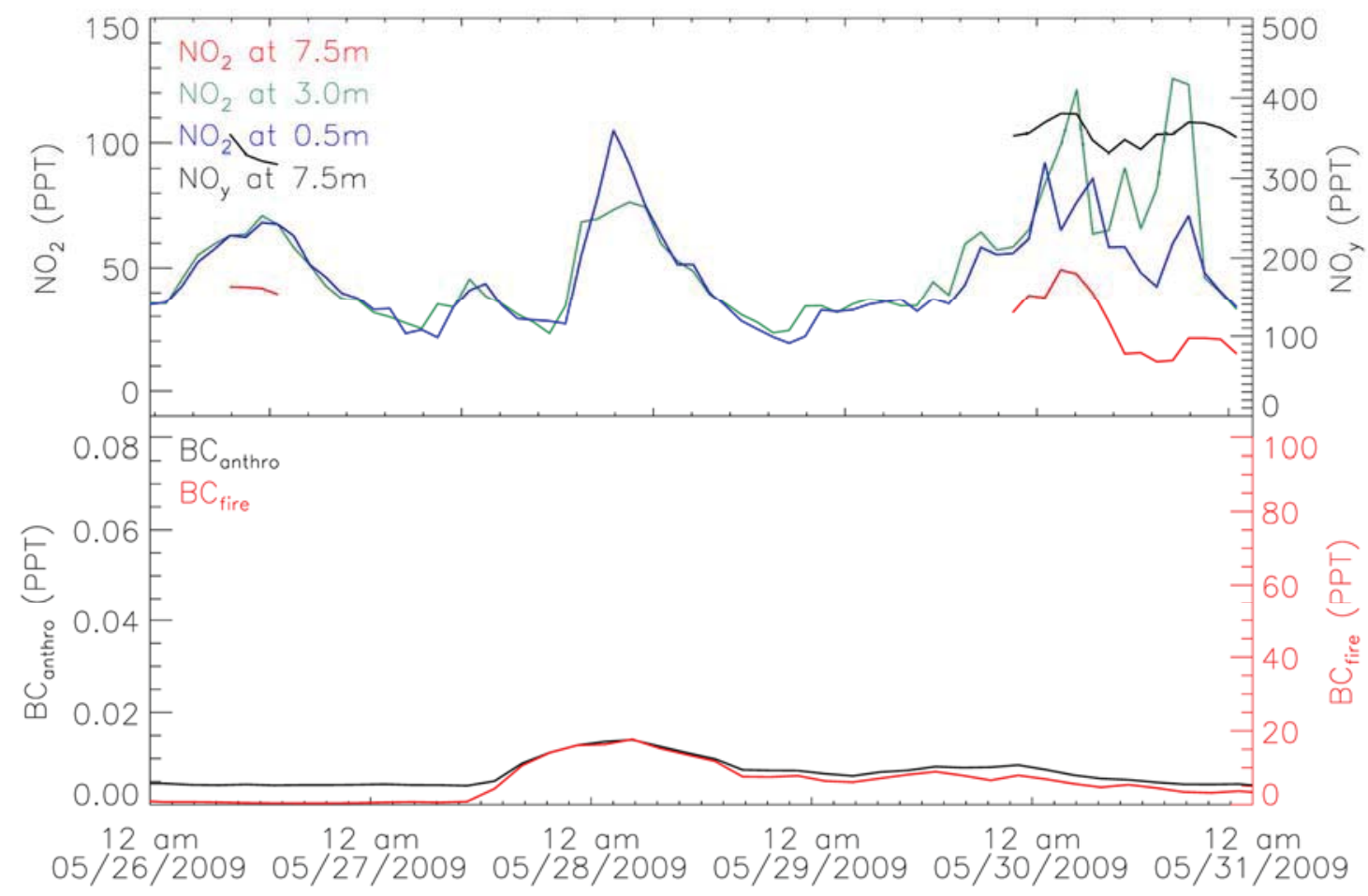

Figure 3.18. Anthropogenic event 45 , which is also identified as biomass burning event 7 . All symbols and definitions are same as Figure 3.15.

Figure 3.19 displays variation of NO mixing ratio during the event. It is in good agreement with FLEXPART simulations, reaching a maximum when both $\mathrm{BC}_{\text {anthro }}$ and $\mathrm{BC}_{\text {fire }}$ tracer reached the maximums. It is always of higher values at $0.5 \mathrm{~m}$ above the snowpack due to snowpack nitrate photolysis. Two smaller peaks were observed after the event. Similarly, they can be explained by missed pollution events by FLEXPAR. They may also be combination effects from nitrate re-emission, pre-existing nitrate photolysis, and/or wind pumping. Therefore, more data and model simulations are needed to investigate this event. 


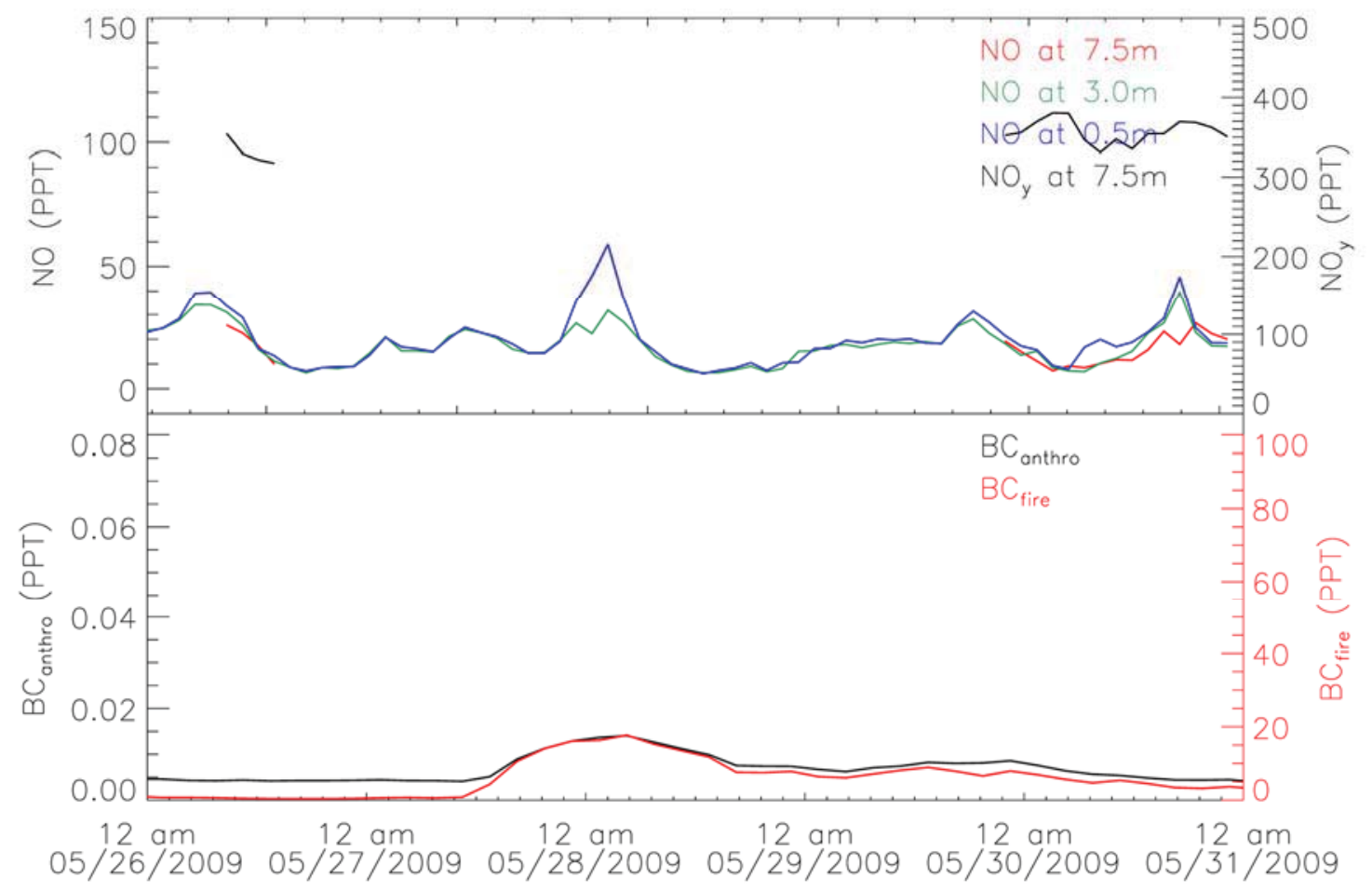

Figure 3.19. NO mixing ratio variations during anthropogenic event 16 (or biomass burning event 7). 


\section{Chapter 4 Conclusions and Future Work}


The thesis focused on the analyses of $\mathrm{NO}$ and $\mathrm{NO}_{2}$ measured at $7.5 \mathrm{~m}, 3 \mathrm{~m}$, and $0.5 \mathrm{~m}$ above the snowpack from July 2008 to July 2010 at Summit, Greenland. Seasonal cycles and diurnal cycles were investigated through $\mathrm{NO}$ and $\mathrm{NO}_{2}$ gradients. Furthermore, pollution events caused by long range transported anthropogenic emissions and biomass burning emissions were identified with FLEXPART retroplume simulations. Due to the challenges from the data, three events with two in polar night season and one in sunlight season were selected and analyzed to study the variation of $\mathrm{NO}$ and $\mathrm{NO}_{2}$ before, during and after the events.

\subsection{Conclusions}

- Both $\mathrm{NO}$ and $\mathrm{NO}_{2}$ showed apparent seasonal cycles at three levels. For NO, higher values from late spring to summer and lower values from fall to early spring plus similar mixing ratios at three levels were observed. For $\mathrm{NO}_{2}$, higher values from early spring to early fall and lower values from fall to late winter plus decreased mixing ratios and weakened seasonal cycle at $7.5 \mathrm{~m}$ above the snowpack were observed. $\mathrm{NO}_{2}$ at three levels all reached the maximum mixing ratios in April, while $\mathrm{NO}$ reached maximums in May or June. $\mathrm{NO}_{2}$ represented most of $\mathrm{NO}_{\mathrm{x}}$ at all levels at Summit. Its monthly average is approximately 4 times, 5.6 times, and 3 times the magnitude of NO monthly average at $7.5 \mathrm{~m}, 3 \mathrm{~m}$, and $0.5 \mathrm{~m}$, respectively.

- The vertical gradients of $\mathrm{NO}$ and $\mathrm{NO}_{2}$ between $3 \mathrm{~m}$ and $0.5 \mathrm{~m}$ above the snowpack suggested the emissions of NO from the surface snowpack. The positive gradient of NO from July to September 2009 was proposed to be caused by wind pumping and pollution from the main camp. An improved mechanism for snowpack photochemistry was proposed to explain the negative $\mathrm{NO}_{2}$ gradient in early spring. Gradients between $7.5 \mathrm{~m}$ and $0.5 \mathrm{~m}$ were always negative due to gas dispersion process except in May 2009, which was most likely caused by long range transport emissions. Wind pumping, pollution from the camp and lower latitudes highly impacted vertical gradients of $\mathrm{NO}$ and $\mathrm{NO}_{2}$ at Summit.

- Apparent diurnal cycles of NO were observed from March to June with high values at around local noon, following the solar radiation variation. For $\mathrm{NO}_{2}$, higher values 
from afternoon till night and lower values from early morning till noon were observed. Diurnal cycles in June were weak which might be caused by outliers. For a photolysis driven variable at Summit, the seasonal cycle is a simplified long diurnal cycle, while the diurnal cycle is a complicated short seasonal cycle.

- Summit was often impacted by anthropogenic emissions and biomass burning emissions mainly transported from Europe and North America. A number of 85 anthropogenic emission events and 13 biomass burning emission events were identified with FLEXPART retroplume analyses under the defined criterion in Section 3.4. The model simulations were in good agreement with the measurements. During polar night season, $\mathrm{NO}_{2}$ exactly followed FLEXPART simulation. Nitrate accumulation through snowpack deposition is proposed to attribute to $\mathrm{NO}_{2}$ increase in early spring. In sunlight season, the deposited nitrate is proposed to be re-emitted from the snowpack via photolysis, resulting in subsequent $\mathrm{NO}_{2}$ increase after the event. 


\subsection{Future work}

Future work will focus on measurements of $\mathrm{NO}_{\mathrm{x}}$ snowpack emissions before and after short period pollution events to quantitatively investigate the proposed nitrate deposition and reemission and evaluate accuracy of chemical transport model simulations. Furthermore, box photochemical modeling of $\mathrm{NO}_{x}, \mathrm{O}_{3}$ and VOCs above the snowpack in spring to verify whether the simulated $\mathrm{O}_{3}$ is equal to the observed data at Summit with NCAR Master Mechanism model. If model simulated $\mathrm{O}_{3}$ is smaller than the observed data, additional $\mathrm{O}_{3}$ source from stratosphere can be verified. By changing the values of input parameters, the correlation between non-methane hydrocarbons (NMHC) decrease and $\mathrm{O}_{3}$ increase in spring will be investigated. 


\section{References}

Altshuller, A. P., and J. J. Bufalini. "Photochemical aspects of air pollution: a review." Photochemistry and photobiology 4.2 (1965): 97-146.

Barrie, L. A., et al. "Anthropogenic aerosols and gases in the lower troposphere at Alert Canada in April 1986." Journal of Atmospheric Chemistry 9.1-3 (1989): 101-127.

Beine, Harald J., et al. "NOx during background and ozone depletion periods at Alert: Fluxes above the snow surface." Journal of Geophysical Research: Atmospheres (19842012) 107.D21 (2002): ACH-7.

Bottenheim, Jan, Allan G. Gallant, and Kenneth A. Brice. "Measurements of NOy species and $\mathrm{O} 3$ at $82 \mathrm{~N}$ latitude." Geophysical Research Letters 13.2 (1986): 113-116.

Bottenheim, Jan W., and Alan J. Gallant. "PAN over the Arctic; observations during AGASP-2 in April 1986." Journal of Atmospheric Chemistry 9.1-3 (1989): 301-316.

Burkhart, John F., et al. "Seasonal accumulation timing and preservation of nitrate in firn at Summit, Greenland." Journal of Geophysical Research: Atmospheres (19842012) 109.D19 (2004).

Chu, Liang, and Cort Anastasio. "Temperature and wavelength dependence of nitrite photolysis in frozen and aqueous solutions." Environmental science \& technology 41.10 (2007): 3626-3632.

Cohen, Lana, et al. "Boundary-layer dynamics and its influence on atmospheric chemistry at Summit, Greenland." Atmospheric Environment 41.24 (2007): 5044-5060.

Crutzen, Paul. "A discussion of the chemistry of some minor constituents in the stratosphere and troposphere." Pure and Applied Geophysics 106.1 (1973): 1385-1399.

Crutzen, Paul J. "The influence of nitrogen oxides on the atmospheric ozone content." Quarterly Journal of the Royal Meteorological Society 96.408 (1970): 320-325. 
Crutzen, Paul J. "The role of NO and NO2 in the chemistry of the troposphere and stratosphere." Annual review of earth and planetary sciences 7 (1979): 443-472.

Delmas, R., D. Serça, and C. Jambert. "Global inventory of NOx sources."Nutrient cycling in agroecosystems 48.1-2 (1997): 51-60.

Demerjian, Kenneth L., James Alistair Kerr, and Jack George Calvert. The mechanism of photochemical smog formation. Wiley, 1974.

Dibb, Jack E., et al. "Fast nitrogen oxide photochemistry in Summit, Greenland snow." Atmospheric Environment 36.15 (2002): 2501-2511.

Dickerson, Russell R. "Reactive nitrogen compounds in the Arctic." Journal of Geophysical Research: Atmospheres (1984-2012) 90.D6 (1985): 10739-10743.

Dubowski, Yael, A. J. Colussi, and M. R. Hoffmann. "Nitrogen dioxide release in the 302 $\mathrm{nm}$ band photolysis of spray-frozen aqueous nitrate solutions. Atmospheric implications." The Journal of Physical Chemistry A 105.20 (2001): 4928-4932.

Fishman, Jack, Susan Solomon, and Paul J. Crutzen. "Observational and theoretical evidence in support of a significant in-situ photochemical source of tropospheric ozone." Tellus 31.5 (1979): 432-446.

France, J. L., et al. "Snow optical properties at Dome C (Concordia), Antarctica; implications for snow emissions and snow chemistry of reactive nitrogen."Atmospheric Chemistry and Physics 11.18 (2011): 9787-9801.

Frey, M. M., et al. "The diurnal variability of atmospheric nitrogen oxides (NO and NO 2) above the Antarctic Plateau driven by atmospheric stability and snow emissions." Atmospheric Chemistry and Physics 13.6 (2013): 3045-3062.

Grannas, A. M., et al. "An overview of snow photochemistry: evidence, mechanisms and impacts." Atmospheric Chemistry and Physics 7.16 (2007): 4329-4373. 
Hastings, Meredith G., E. J. Steig, and D. M. Sigman. "Seasonal variations in N and O isotopes of nitrate in snow at Summit, Greenland: Implications for the study of nitrate in snow and ice cores." Journal of Geophysical Research: Atmospheres (19842012) 109.D20 (2004).

Honrath Jr, Richard Edward. Nitrogen oxides in the Arctic troposphere. Alaska Univ., Fairbanks, AK (United States), 1991.

Honrath, R. E., et al. "Evidence of NOx production within or upon ice particles in the Greenland snowpack." Geophysical Research Letters 26.6 (1999): 695-698.

Honrath, R. E., et al. "Vertical fluxes of NO x, HONO, and HNO 3 above the snowpack at Summit, Greenland." Atmospheric Environment 36.15 (2002): 2629-2640.

Howard, Carleton J., and K. M. Evenson. "Kinetics of the reaction of $\mathrm{HO} 2$ with NO." Geophysical Research Letters 4.10 (1977): 437-440.

Jacobi, Hans-Werner, and Birgit Hilker. "A mechanism for the photochemical transformation of nitrate in snow." Journal of Photochemistry and Photobiology A: Chemistry 185.2 (2007): 371-382.

Jones, A. E., et al. "Speciation and rate of photochemical NO and NO2 production in Antarctic snow." Geophysical Research Letters 27.3 (2000): 345-348.

Kramer, L. J., et al. "Seasonal variability of atmospheric nitrogen oxides and non-methane hydrocarbons at the GEOSummit station, Greenland."Atmospheric Chemistry and Physics 15.12 (2015): 6827-6849.

Levy, H. "Normal atmosphere: Large radical and formaldehyde concentrations predicted." Science 173.3992 (1971): 141-143.

Levy, Hiram. "Tropospheric budgets for methane, carbon monoxide, and related species." Journal of Geophysical Research 78.24 (1973): 5325-5332. 
Liu, S. C., et al. "Ozone production in the rural troposphere and the implications for regional and global ozone distributions." Journal of Geophysical Research: Atmospheres (1984-2012) 92.D4 (1987): 4191-4207.

Logan, Jennifer A. "Nitrogen oxides in the troposphere: Global and regional budgets." Journal of Geophysical Research: Oceans (1978-2012) 88.C15 (1983): 1078510807.

Logan, Jennifer A., et al. "Tropospheric chemistry: A global perspective."Journal of Geophysical Research: Oceans (1978-2012) 86.C8 (1981): 7210-7254.

Navas, M. J., A. M. Jiménez, and G. Galan. "Air analysis: determination of nitrogen compounds by chemiluminescence." Atmospheric Environment 31.21 (1997): 3603-3608.

Pollack, Ilana B., Brian M. Lerner, and Thomas B. Ryerson. "Evaluation of ultraviolet light-emitting diodes for detection of atmospheric NO2 by photolysischemiluminescence." Journal of atmospheric chemistry 65.2-3 (2010): 111-125.

Ridley, Brian A., et al. "NO and NO2 in the troposphere: Technique and measurements in regions of a folded tropopause." Journal of Geophysical Research: Atmospheres (19842012) 93.D12 (1988): 15813-15830.

Sandholm, S. T., et al. "Summertime tropospheric observations related to $\mathrm{N}$ x O y distributions and partitioning over Alaska: Arctic Boundary Layer Expedition 3A." Journal of Geophysical Research: Atmospheres (1984-2012) 97.D15 (1992): 1648116509.

Seinfeld, John H., and J. H. Seinfeld. Air pollution: physical and chemical fundamentals. Vol. 523. New York: McGraw-Hill, 1975.

Seok, Brian, et al. "An automated system for continuous measurements of trace gas fluxes through snow: an evaluation of the gas diffusion method at a subalpine forest site, Niwot Ridge, Colorado." Biogeochemistry 95.1 (2009): 95-113. 
Stephens, Edgar R. The formation, reactions, and properties of peroxyacyl nitrates (PANs) in photochemical air pollution. Wiley, 1969.

Singh, Hanwant B., and Philip L. Hanst. "Peroxyacetyl nitrate (PAN) in the unpolluted atmosphere: An important reservoir for nitrogen oxides."Geophysical Research Letters 8.8 (1981): 941-944.

Singh, Hanwant B., Louis J. Salas, and William Viezee. "Global distribution of peroxyacetyl nitrate." (1986): 588-591.

Singh, Hanwant B. "Reactive nitrogen in the troposphere." Environmental science \& technology 21.4 (1987): 320-327.

Singh, H. B., et al. "Relationship of peroxyacetyl nitrate to active and total odd nitrogen at northern high latitudes: Influence of reservoir species on NO x and O3." Journal of Geophysical Research: Atmospheres (1984-2012) 97.D15 (1992): 16523-16530.

Stohl, A., et al. "Technical note: The Lagrangian particle dispersion model FLEXPART version 6.2." Atmospheric Chemistry and Physics 5.9 (2005): 2461-2474.

Stohl, A. "Characteristics of atmospheric transport into the Arctic troposphere."Journal of Geophysical Research: Atmospheres (1984-2012) 111.D11 (2006).

Toro, Claudia. Nitrogen oxides in the firn air at Summit, Greenland. Michigan Technological University, Houghton, MI, 2011.

Villena, G., et al. "Interferences of commercial NO 2 instruments in the urban atmosphere and in a smog chamber." Atmospheric Measurement Techniques5.1 (2012): 149-159.

Van Dam, B., et al. "Evaluation of Boundary Layer Depth Estimates at Summit Station, Greenland." Journal of Applied Meteorology and Climatology 52.10 (2013): 2356-2362.

Warneck, Peter, and Christa Wurzinger. "Product quantum yields for the 305-nm photodecomposition of nitrate in aqueous solution." The Journal of Physical Chemistry 92.22 (1988): 6278-6283. 
Zimmerman, Patrick R., et al. "Estimates on the production of $\mathrm{CO}$ and $\mathrm{H} 2$ from the oxidation of hydrocarbon emissions from vegetation." Geophysical Research Letters 5.8 (1978): 679-682. 